\title{
PRAVNI OKVIR ZA ZAŠTITU OSOBNIH PODATAKA (U VEZI SA ZDRAVLJEM) U PRAVU EUROPSKE UNIJE
}

Dr. sc. Marko Bevanda, izvanredni profesor

Pravni fakultet Sveučilišta u Mostaru

Dr. sc. Maja Čolaković, izvanredna profesorica Pravni fakultet Univerziteta „Džemal Bijedić““ u Mostaru, Bosna i Hercegovina
UDK: 342.738:613.8(4)

Ur.: 29. veljače 2016.

Pr.: 15. ožujka 2016.

Izvorni znanstveni rad

Data protection is a democratic value and it can reinforce democracy in the digital age. ${ }^{l}$ We should value our privacy because the control of our own personal information is essential to our sense of self. ${ }^{2}$

Giovanni Buttarelli, Europski nadzornik za zaštitu podataka

\begin{abstract}
Sažetak
Pravo na zaštitu osobnih podataka temeljno je pravo sadržano u nizu međunarodnih $i$ nacionalnih pravnih dokumenata. Posebnu zaštitu uživaju osobni podatci u vezi sa zdravstvenim stanjem. Važnost prava na zaštitu osobnih podataka (u vezi sa zdravljem) naglašava i sudska praksa Europskog suda za ljudska prava i Suda Europske unije. Autori u ovome radu daju prikaz najznačajnijih pravnih izvora iz područja zaštite osobnih (zdravstvenih) podataka u pravu Europske unije i relevantne sudske prakse Europskog suda za ljudska prava $i$ Suda Europske unije, te se osvrću na sadašnju iznimno složenu reformu okvira za zaštitu (osobnih) podataka u Europskoj uniji.
\end{abstract}

Ključne riječi: privatnost, osobni podatci, Direktiva 95/46/EZ, zaštita osobnih zdravstvenih podataka.

1 Data protection as a bulwark for digital democracy, Keynote speech at the 6th International e Democracy 2015 Conference on Citizen rights in the world of the new computing paradigms Athens, 10 December 2015, https://secure.edps.europa.eu/EDPSWEB/webdav/site/mySite/ shared/Documents/EDPS/Publications/Speeches/2015/15-12-10_eDemocracy_EN.pdf (30.1.2016.).

2 A New Year, a new chapter, http://neurope.eu/article/a-new-year-a-new-chapter/ (30.1.2016.). 


\section{1. $U$ VOD}

Posljednjih godina nijedno područje unutar Europske unije nije probudilo toliko veliki interes i zadobilo naročitu pozornost javnosti, ali i stručnjaka iz različitih znanstvenih disciplina, kao što je to učinilo područje zaštite osobnih podataka. Današnje vrijeme revolucije ,velikih podataka” (engl. Big data), odnosno vrijeme dostupnosti velike količine podataka, raznolikosti tipova podataka, velike brzine akumulacije i dostupnosti novih podataka, donosi velike prednosti, ali i ogromne izazove. ${ }^{3}$ Europski građani sude o Europskoj uniji i po njezinim sposobnostima da odgovori na najveće izazove s kojima se danas suočavaju naša društva, ${ }^{4}$ a jedan od tih izazova svakako je postizanje visoke razine zaštite osobnih podataka, uključujuću podatke o zdravlju pojedinca.

Pravo na zaštitu osobnih podataka temeljno je pravo sadržano u nizu međunarodnih i nacionalnih pravnih dokumenata. Ustavi brojnih država jamče sigurnost i tajnost osobnih podataka, te utvrđuju pravo svakog pojedinca na zaštitu osobnih podataka. ${ }^{5} \mathrm{U}$ pravnoj literaturi se ističe da je zaštita osobnih podataka jedna od podvrsta zaštite prava osobnosti (prava ličnosti). ${ }^{67}$

3 KOCIJAN, Kristina, Big Data: kako smo došli do Velikih podataka i kamo nas oni vode, u: Komunikacijski obrasci i informacijska znanost (urednici: Vrana, Radovan i Pečarić, Đilda), Zagreb, 2014., str. 37. - 62., http://darhiv.ffzg.unizg.hr/5064/1/KocijanK_BigData.pdf; Vidi: Europska komisija, Priopćenje za tisak, Bruxelles, 2. srpnja 2014., http://europa.eu/rapid/ press-release_IP-14-769_hr.pdf (16.1.2016.).

4 Komunikacija Komisije Europskom parlamentu, Vijeću, Europskom gospodarskom i socijalnom odboru i Odboru regija, Program rada Komisije za 2016., Vrijeme je za drugačiji način rada, COM(2015) 610 final, Strasbourg, 27.10.2015.

5 Tako je primjerice člankom 37. Ustava Republike Hrvatske (Narodne novine br. 56/90., 135/97., 8/98., 113/00., 124/00., 28/01., 41/01., 55/01., 76/10., 85/10., 05/14. - pročišćeni tekst) propisano: „Svakom se jamči sigurnost i tajnost osobnih podataka. Bez privole ispitanika, osobni se podaci mogu prikupljati, obrađivati i koristiti samo uz uvjete određene zakonom. Zakonom se uređuje zaštita osobnih podataka te nadzor nad djelovanjem informatičkih sustava u državi. Zabranjena je uporaba osobnih podataka suprotna utvrđenoj svrsi njihovoga prikupljanja“.

$6 \quad, \ldots$ jer je protupravnom povredom osobnih podataka o fizičkim osobama moguća povreda ne samo prava na privatnost nego i prava na ugled, čast i dostojanstvo, te prava na duševni integritet pojedine osobe.", MAGANIĆ, Aleksandra, Zaštita prava osobnosti, u: Trideset godina Zakona o obligacionim odnosima - de lege lata i de lege ferenda, Beograd, 2009., str. 437.; Vidi: RADOLOVIĆ, Aldo, Pravo osobnosti u novom Zakonu o obveznom odnosima, Zbornik Pravnog fakulteta Sveučilišta u Rijeci, vol. 27., no. 1., 2006., str. 129. - 170.; BARETIĆ, Marko, Pojam i funkcije neimovinske štete prema novom Zakonu o obveznim odnosima, Zbornik Pravnog fakulteta u Zagrebu, vol. 56., Poseban broj, 2006., str. 461.- 500; RADOLOVIĆ, Aldo, Specifični postupovnopravni problemi u zaštiti prava osobnosti, Zbornik Pravnog fakulteta u Zagrebu, vol. 63., no. 3-4., 2013., str. 695. - 715.; RADOLOVIĆ, Aldo, Pravni poslovi prava osobnosti, Zbornik Pravnog fakulteta Sveučilišta u Rijeci, vol. 35., no. 1., 2014., str. 95. - 118.; BUKOVAC PUVAČA, Maja, Deset godina nove koncepcije neimovinske štete, Zbornik Pravnog fakulteta Sveučilišta u Rijeci, vol. 36., no. 1., 2015., str. 157. -180 .

7 „tajnost osobnih podataka (engl. secrecy of personal dana; njem. Verschwiegenheit der Personenstanden; franc. Secret de l'etat civil) osobno pravo kojim svaka fizička osoba ima 
Važnost temeljnog prava na zaštitu osobnih podataka je neupitna. Svrha zaštite osobnih podataka je osigurati ostvarenje i zaštitu privatnog života (prava na privatnost $)^{8} \mathrm{i}$ ostalih ljudskih prava $\mathrm{i}$ temeljnih sloboda $\mathrm{u}$ prikupljanju, obradi i korištenju osobnih podataka. ${ }^{9}$ Temeljno pravo na zaštitu osobnih podataka ipak nije apsolutno pravo, nego pravo koje je podložno određenim ograničenjima. To je pravo uvjetovano svojim općim društvenim značenjem, odnosno općim interesima i zaštitom prava i sloboda drugih osoba.

Posebnu zaštitu uživaju osobni podatci u vezi sa zdravstvenim stanjem. ${ }^{10}$ Podatci u vezi sa zdravljem pojedinca bitan su element privatnog života i ulaze u posebnu kategoriju podataka. S obzirom na svoju prirodu ti osjetljivi podatci pri obradi mogu predstavljati rizik za njihove ,vlasnike“ i treba ih dodatno zaštiti. ${ }^{11}$ Rizik od otkrivanja osobnih podataka u vezi sa zdravstvenim stanjem čini sve pojedince (pacijente) ranjivom kategorijom osoba. ${ }^{12}$ Kako ističu neki autori, ${ }^{13}$ osobni zdravstveni podatci su vrlo osjetljiva kategorija podataka čije neopravdano objavljivanje može prouzročiti posramljenost, stigmatizaciju i diskriminaciju pojedinca u društvu, odnosno povredu osobnih neimovinskih dobara osobe čiji su zdravstveni podatci objavljeni. To može dovesti i do nastanka odnosa odgovornosti za štetu.

zaštitu tajnosti svojih osobnih podataka, a radi ostvarenja prava na privatnost, što je jedno od prava osobnosti i ostalih ljudskih prava i temeljnih sloboda“, Pravni leksikon, Zagreb, 2007., str. 1596.

8 Neki autori naglašavaju da je pojam privatnog života mnogo širi od pojma privatnosti, „obuhvaćajući oblast u kojoj svaki pojedinac može da slobodno razvija i ispunjava svoju ličnost, kako u odnosu s drugima tako i prema spoljašnjem svetu.“, ROAGNA, Ivana, Zaštita prava na poštivanje privatnog i porodičnog života prema Evropskoj konvenciji o ljudskim pravima, Vijeće Europe, Strasbourg, 2012., str. 14., http://www.coe.int/t/dgi/hr-natimplement/Source/ documentation/hb11_privatelife_bosnian.pdf (12.1.2016.).

9 Vidi primjerice: čl. 1. hrvatskoga Zakona o zaštiti osobnih podataka (Narodne novine, br. 103/03., 118/06., 41/08., 130/11. i 106/12. - pročišćeni tekst); čl. 1. slovenskoga Zakona o varstvu osebnih podatkov (Uradni list RS, št. 86704., 67/07., 94/07.- pročišćeni tekst); čl. 1. Zakona o zaštiti osobnih podataka Bosne i Hercegovine (Službeni glasnik BiH, br. 49/06., 76/11. i 89/11.).

10 „U okviru zaštite osobnih podataka posebno mjesto zauzima zaštita medicinskih osobnih podataka. Podaci o zdravstvenom stanju osoba vrlo su značajni, spadaju u specifične podatke i potrebne su stroge norme koje će regulirati pristup tim podacima u pogledu ovlaštenih osoba i pod kojim uvjetima. Zahtijeva se točnost tih podataka, ali je isto tako potreban i brz pristup.“, DULČIĆ, Katerina, BODIROGA-VUKOBRAT, Nada, Zaštita osobnih podataka pacijenta u europskom i hrvatskom pravu, Zbornik Pravnog fakulteta Sveučilišta u Rijeci, vol. 29., no. 1., 2008., str. 373.

11 Priručnik o europskom zakonodavstvu o zaštiti podataka, Agencija Europske unije za temeljna prava, Vijeće Europe, Luksemburg: Ured za publikacije Europske unije, 2014., str. 41., http://www.echr.coe.int/Documents/Handbook_data_protection_HRV.pdf (dalje u tekstu: Priručnik o zaštiti podataka 2014.) (15.1.2016.).

12 GROZDANIĆ, Velinka, ŠKORIĆ, Marissabell, RITTOSSA, Dalida, Liječnička tajna u funkciji zaštite privatnosti osoba s duševnim smetnjama, Zbornik Pravnog fakulteta u Zagrebu, vol. 64., br. 5-6., 2014., str. 835.

13 ORENTLICHER, David, Prescription Dana Mining and the Protection of Patients' Interests, Journal of Law, Medicine \& Ethics, Vol. 38., No. 1., 2010., str. 76. 
Važnost kako temeljnog prava na poštovanje privatnog života tako i temeljnog prava na zaštitu osobnih podataka (u vezi sa zdravljem) zajamčenih brojnim međunarodnim i nacionalnim pravnim dokumentima naglašava i sudska praksa Europskog suda za ljudska prava i Suda Europske unije (dalje u tekstu: Sud EU). ${ }^{14}$

Danas je posebice važno pitanje prekograničnog prijenosa, upotrebe i zaštite osobnih podataka o zdravlju pacijenata. Snažan razvoj zdravstvenih inovacija ${ }^{15}$ i sustava mobilnog zdravstva (m-zdravstvo) ${ }^{16}$ omogućio je prikupljanje i obradu velike količine zdravstvenih podataka osoba pri uporabi tehnologija mobilnog zdravstva, te je otvorio pitanje sigurnosti i zaštite istih. ${ }^{17} \mathrm{M}$-zdravstvo nudi brojne nove mogućnosti u smislu boljeg i odgovornijeg zdravstva za pojedince (potrošače, pacijente), ${ }^{18}$ ali ima i nedostatke koji mogu negativno utjecati na prava pojedinaca na privatnost i zaštitu osobnih podataka. ${ }^{19}$ Brojne internetske usluge i mobilne aplikacije vezane za zdravlje stavljaju se na internetsko tržište kao „besplatne”, ali zapravo zahtijevaju plaćanje u obliku osobnih podataka u vezi sa zdravstvenim stanjem koje pružaju pojedinci, što može predstavljati poseban rizika za njihovu dobrobit, pravo na privatnost i zaštitu podataka zbog zlouporabe, nezakonitog

14 Sud Europske unije čine tri suda: Sud, Opći sud (osnovan 1988.) i Službenički sud (osnovan 2004.), a njihovo je sjedište u Luxembourgu, http://curia.europa.eu/, Vidi: RODIN, Siniša, Europski sud kao najviši sud Europske unije, Informator, br. 6242-6243, Zagreb, 2014., str. 1. -3 .

15 Jedan od posebnih ciljeva trećeg Programa djelovanja Unije u području zdravlja (2014 2020) je promicanje dobrovoljne primjene zdravstvenih inovacija i e-zdravstva povećanjem interoperabilnosti registara pacijenata $\mathrm{i}$ drugih rješenja e-zdravstva, te podrška suradnji $\mathrm{u}$ vezi s e-zdravstvom u Uniji, posebno u pogledu registara, i njegovoj primjeni od strane zdravstvenih djelatnika. Vidi čl. 3.(3) i toč. 3. priloga I. „Doprinos inovativnim, učinkovitim i održivim zdravstvenim sustavima“ Uredbe (EU) br. 282/2014 Europskog parlamenta i Vijeća od 11. ožujka 2014. o uspostavi trećeg Programa djelovanja Unije u području zdravlja (2014. - 2020.) i o stavljanju izvan snage Odluke br. 1350/2007/EZ (Tekst značajan za EGP), Službeni list L 86, 21. 3. 2014.

16 Kako se navodi u Zelenoj knjizi o mobilnom zdravstvu Europske komisije (Bruxelles, 10. 04. 2014., $\operatorname{COM(2014)~} 219$ final) pod pojmom „mobilno zdravstvo“ kako ga definira Svjetska zdravstvena organizacija smatra se liječnička praksa i praksa javnog zdravstva uz potporu mobilnih uređaja, kao što su mobilni telefoni, uređaji za praćenje pacijenata, osobni digitalni pomoćnici i drugi bežični uređaji.

17 Vidi: Radni dokument službi Komisije o postojećem pravnom okviru koji se primjenjuje na aplikacije o načinu života i dobrobiti: U prilog Zelenoj knjizi o mobilnom zdravstvu (m-zdravstvu) (COM(2014) 135 završna verzija od 10.04.2014.).

18 „Informacijske i komunikacijske tehnologije mogu pridonijeti tako što će europskim građanima osigurati bolje, jeftinije i kvalitetnije usluge u zdravstvu i socijalnoj skrbi te omogućiti kvalitetno starenje. Procjenjuje se da će se samo uvođenjem informacijskih i komunikacijskih tehnologija i telemedicine učinkovitost zdravstvene skrbi povećati za 20 \%.“, Politike Europske unije: Digitalna agenda za Europu, Ured za publikacije Europske unije, Luxembourg, 2014., str. 6.

19 Izvršni sažetak mišljenja Europskog nadzornika za zaštitu podataka o mobilnom zdravstvu: usklađivanje tehnološke inovacije sa zaštitom podataka, Službeni list EU C 232, 16. 07. 2015., str. 8. -10 . 
i neopravdanog korištenja $\mathrm{i}$ objavljivanja tih podatka. ${ }^{20,21}$ Osobni podatci o zdravstvenom stanju u suvremenom digitalnom svijetu i sve razvijenijem mobilnom zdravstvu imaju veliku vrijednost (valuta digitalnog svijeta), ${ }^{22}$ jer bez takvih podataka (informacija) mobilno zdravstvo ne bi moglo niti nastati, kao i uspješno se razvijati i prilagođavati neprestanim promjenama u suvremenom društvu i digitalnom okruženju.

Iznimno je opasno, pravno i etički neprihvatljivo kada zdravstvene ustanove, privatne prakse, trgovačka društva (za obavljanje zdravstvene djelatnosti), liječnici ili drugi zdravstveni radnici koji posjeduju podatke vezane uz zdravlje neke osobe te podatke koriste u svrhu ostvarenja materijalne ili druge vrste koristi za sebe, što je protivno svrsi za koju su prikupljeni, a to je dobrobit pacijenta (npr. liječnik otkriva zdravstvene podatke svojih pacijenata nekoj farmaceutskoj kompaniji, koja zauzvrat financira njegov poslijediplomski doktorski studij). ${ }^{23}$ Obveza povjerljivosti i čuvanja osobnih podataka o pacijentu i njegovom zdravstvenom stanju otvara niz važnih, složenih i osjetljivih pravnih i etičkih pitanja, dvojbi i problema. Koja je pravna priroda prava na zaštitu osobnih podataka pacijenta, tko ulazi u krug osoba obveznih čuvati medicinske informacije o pacijentu (čuvanje profesionalne tajne), ${ }^{24}$ koji je predmet obveze čuvanja, koji su razlozi koji opravdavaju otkrivanje osobnih podataka u vezi sa zdravstvenim stanjem, itd.? Posebice je važno pitanje (građanskopravne) odgovornosti za povredu temeljnog prava na zaštitu osobnih

20 Izvršni sažetak Preliminarnog mišljenja Europskog nadzornika za zaštitu podataka o privatnosti i konkurentnosti u razdoblju velike količine podataka, Službeni list EU C 225, 16. 07. 2014., str. 6. -9 .

21 Prema ispitivanju Eurobarometra o zaštiti podataka u lipnju 2015. više od osam od deset građana (ispitanika) ističu da nemaju potpunu kontrolu nad svojim osobnim podatcima, a dvije trećine zabrinute su što nemaju potpunu kontrolu nad informacijama koje dostavljaju putem interneta, ispitanici su najviše zabrinuti za zapise njihovih aktivnosti kod kartičnog plaćanja i upotrebe mobilnih telefona i aplikacija, Posebni Eurobarometar br. 431 o zaštiti podataka, http://ec.europa.eu/public_opinion/archives/ebs/ebs_431_en.pdf; Prema ispitivanju Eurobarometra o zaštiti podataka u Republici Hrvatskoj (Eurobarometar 83.1, rezultati za Hrvatsku, 2015.) od različitih tijela (državna tijela, lokalne vlasti, agencije) i privatnih tvrtki ispitanici (građani RH) najviše vjeruju zdravstvenim (medicinskim) ustanova da će zaštititi njihove osobne podatke, a najmanje povjerenja imaju u operatere fiksne i mobilne telefonije, pružatelje internetskih usluga, te internetske servise (tražilice, društvene mreže, usluge elektroničke pošte)., http://ec.europa.eu/public_opinion/archives/ebs/ebs_431_fact_hr_hr.pdf (15.2.2016.).

22 „Personal data is the new oil of the internet and the new currency of the digital world.“ KUNEVA, Meglena European Consumer Commissioner, Keynote Speech (Speech/09/156), Roundtable on Online Data Collection, Targeting and Profiling, Brussels, 31 March 2009., http://europa.eu/rapid/press-release_SPEECH-09-156_en.htm (12.1.2016.).

23 Vidi: ORENTLICHER, David, op. cit. u bilj. 13., str. $\overline{74}$. -84.

24 Vidi. ČIZMIĆ, Jozo, Pravo pacijenta na obaviještenost, s posebnim osvrtom na zaštitu tajnosti podataka o zdravstvenom stanju pacijenta, Zbornik Pravnog fakulteta Sveučilišta u Rijeci, vol. 29., no. 1., 2008., 243. - 250. 
podataka (nezakonito objavljivanje osobnih podataka u vezi sa zdravljem). ${ }^{25,26}$

Unutar sadašnjeg europskog sustava pravne zaštite temeljnog prava na poštovanje privatnog života i prava na zaštitu osobnih podataka postavlja se pitanje primjene i učinkovitog balansiranja između mnogobrojnih interesa, posebice interesa pacijenta, davatelja zdravstvene usluge i općeg društvenog interesa. Sadašnjom iznimno složenom reformom pravnog okvira za zaštitu (osobnih) podataka u Europskoj uniji nastoji se odgovoriti na ključne izazove suvremenog digitalnog svijeta.

\section{PRAVNI IZVORI}

\subsection{Uvod}

Današnji sustav zaštite podataka u Europi zasniva se na Konvenciji br. 108 Vijeća Europe, pravnim aktima Europske unije (EU), te sudskoj praksi Europskog suda za ljudska prava i Suda Europske unije. ${ }^{27,28}$

25 Sukladno članku 340. stavku 2. Ugovora o funkcioniranju Europske unije (UFEU): “u pogledu izvanugovorne odgovornosti Unija je, u skladu s općim načelima koja su zajednička pravima država članica, dužna nadoknaditi svaku štetu koju njezine institucije ili službenici prouzroče pri obavljanju svojih dužnosti.“" Prema praksi Suda EU-a da bi postojala izvanugovorna odgovornost Unije u smislu članka 340. stavka 2. UFEU-a zbog nezakonitog postupanja njezinih tijela, potrebno je kumulativno ispunjenje nekoliko pretpostavki: 1 . postupanje institucije mora biti protupravno; 2 . mora biti pretrpljena šteta; 3 . mora postojati uzročna veza između spornog postupanja (štetne radnje) i prouzročene štete (koju tužitelj mora dokazati). Vidi presudu Općeg suda (šesto vijeće) od 3. prosinca 2015. u predmetu T-343/13 CN protiv Europskog parlamenta (ECLI:EU:T:2015:926) povodom odštetnog zahtjeva radi ishođenja naknade štete koju je tužitelj navodno pretrpio zbog prenošenja određenih uz njega vezanih osobnih podataka na internetskoj stranici Parlamenta.

26 Jedan od najuglednijih svjetskih izdavača Springer objavio je 2016. godine knjigu pod naslovom: Damages for Violations of Human Rights: A Comparative Study of Domestic Legal Systems, (BAGIŃSKA, Ewa, urednica, Ius Comparatum - Global Studies in Comparative Law, Vol. 9, 1st ed., 2016.). U navedenoj knjizi autori daju prikaz odštetne odgovornosti za kršenje ljudskih prava u nacionalnim pravnim sustavima (Hrvatska, Češka, Estonija, USA, Velika Britanija, Turska itd.) i pravu Europske unije, odnosno praksi suda EU-a. http://www.springer.com/us/book/9783319189499.; Značajno je napomenuti da je isti izdavač objavio i knjigu pod naslovom: The Influence of Human Rights and Basic Rights in Private Law (Urednici: TRSTENJAK, Verica, WEINGERL, Petra (Eds.), Ius Comparatum - Global Studies in Comparative Law, vol. 15, 1st ed., 2016., http://www.springer.com/us/ book/9783319253350.

27 Priručnik o zaštiti podataka 2014., str. 3.

28 U pravnoj literaturi (MILADIN, Petar, Odgovornost za zaštitu osobnih podataka u bankarstvu, u: Odgovornost za neimovinsku štetu zbog povrede prava osobnosti (ALABURIĆ, Vesna i dr.), Zagreb, 2006., str. 322. i 323.) se ističe kako su pravna vrela prava na zaštitu osobnih podataka kao prava osobnosti višeslojna i o njima nema jednodušnog stajališta u poredbenom pravu. U Republici Hrvatskoj je Zakon o obveznim odnosima (Narodne novine, br. 35/05., 41/08., 125/11., 78/15.) ključan privatnopravni izvor prava na zaštitu osobnih podataka kao posebnog prava osobnosti. 
Prvi dokument na međunarodnoj razini značajan za zaštitu prava na privatni život jest Opća deklaracija o ljudskim pravima, ${ }^{29}$ usvojena i proglašena na Općoj skupštini Ujedinjenih naroda, Rezolucijom 217 A (III), 10. prosinca 1948. godine..$^{30}$ Ona u svome članku 12. jasno iznosi pravo svake osobe na poštovanje privatnog i obiteljskog života, doma i dopisivanja. Ta odredba glasi: „Nitko ne smije biti podvrgnut samovoljnom miješanju u njegov privatni život, obitelj, dom ili dopisivanje, niti napadima na njegovu čast i ugled. Svatko ima pravo na zakonsku zaštitu protiv takvog miješanja ili napada."

Pravo na privatnost ${ }^{31}$ dio je prava zaštićenih člankom 8 . Konvencije za zaštitu ljudskih prava i temeljnih sloboda ${ }^{32}$ (Rim, 1950.) kojim se jamči pravo na poštovanje privatnog i obiteljskog života, doma i dopisivanja te propisuju uvjeti u kojima su dopuštena ograničenja toga prava. U navedenom članku stoji sljedeće: „1. Svatko ima pravo na poštovanje svoga privatnog i obiteljskog života, doma i dopisivanja. ${ }^{33}$ 2. Javna vlast se neće miješati u ostvarivanje tog prava, osim $u$

29 http://www.un.org/en/universal-declaration-human-rights/. Na temelju članka 32. Zakona o sklapanju i izvršavanju međunarodnih ugovora (Narodne novine, br. 28/96.), Vlada Republike Hrvatske je, na sjednici održanoj 12. studenoga 2009. godine, donijela Odluku o objavi Opće deklaracije o ljudskim pravima.

30 Vidi: HANNUM, HURST, The Status of the Universal Declaration of Human Rights in National and International Law, Georgia Journal of International and Comparative Law, vol. 25., 1995., str. 287. - 354., http://ssrn.com/abstract=1957798; MATKOVIĆ, Ante, Postanak Opće deklaracije o pravima čovjeka, Crkva u svijetu, vol. 4., no. 1., 1969., str. 5. - 16., http:// hrcak.srce.hr/ (3.2.2016.).

31 Pravo na privatnost kao relativno novi pravni koncept iznijeli su dvojica bostonskih odvjetnika Samuel D. Warren i Louis D. Brandeis još davne 1890. godine u poznatome članku pod nazivom „The Right of Privacy“ (Harvard Law Review, vol. 4, br. 5, 1890., str. 193. - 220., http://www.jstor.org/stable/1321160). U navedenom članku autori analiziraju brojne slučajeve vezane za osobna prava i iz njih zaključuju da postoji posebno osobno pravo pravo na privatnost, odnosno „pravo da nas se ostavi na miru - the right to be let alone“. Thomas M. Cooley u knjizi pod nazivom „A Treatise of the Law of Torts or the Wrongs Which Arise Independent of Contract" Chicago, 1879., str. 29. kao posebno pravo pojedinca izdvaja ,personal immunity“: The right to one's person may be said to be a right of complete immunity: to be let alone. Jedna od prvih definicija prava na privatnost nalazi se u slučaju Brents v. Morgan (Court of Appeals of Kentucky, 221 Ky. 765, 1927): ,A new branch of the law has been developed in the last few years which has found place in the text-books and the opinions of courts which is denominated the right of privacy. It has not been concretely defined, and probably is not subject to a concrete definition, but it is generally recognized as the right to be let alone; that is, the right of a person to be free from unwarranted publicity, or the right to live without unwarranted interference by the public about matters with which the public is not necessarily concerned., https://casetext.com/case/brents-v-morgan (13.1.2016.).

32 Višestrani međunarodni sporazum sklopljen u okviru Vijeća Europe (stupio na snagu 3. rujna 1953.)., http://www.coe.int/en/web/conventions/search-on-treaties/-/conventions/treaty/005.

33 Europski sud za ljudska prava u presudi od 12. lipnja 2014. (predmet Marić protiv Hrvatske, zahtjev br. 50132/12) ističe da su koncepti privatnog i obiteljskog života široki pojmovi koji nisu podložni iscrpnoj definiciji. Pojam "privatni život” širok je pojam koji podrazumijeva fizički (tjelesni) i psihički integritet osobe, te ponekad može obuhvatiti vidove tjelesnog i društvenog identiteta pojedinca. (toč. 53. presude Europskog suda za ljudska prava od 7. veljače 2002. u predmetu Mikulić protiv Hrvatske, zahtjev br. 53176/99) Informacije o zdravlju osobe bitan su element privatnog života (toč. 66. presude Europskog suda za ljudska 
skladu sa zakonom ${ }^{34} \mathrm{i}$ ako je u demokratskom društvu nužno radi interesa državne sigurnosti, javnog reda i mira, ili gospodarske dobrobiti zemlje, te radi sprečavanja nereda ili zločina, radi zaštite zdravlja ili morala ili radi zaštite prava i sloboda drugih. ${ }^{\text {"“5 }}$ Europskom konvencijom za zaštitu ljudskih prava izričito se ne jamči pravo na zaštitu osobnih podataka. Međutim, ovo se pravo smatra od temeljne važnosti za uživanje prava na privatni život. ${ }^{36}$ Prema članku 6. stavku 3. Ugovora o Europskoj uniji temeljna prava, kako su zajamčena Europskom konvencijom za

prava od 04. prosinca 2008. u predmetu $S$ i Marper protiv Ujedinjenog Kraljevstva, zahtjevi br. 30562/04 i 30566/04).; Europski sud za ljudska prava u svojoj poznatoj presudi od 25. veljače 1997. godine u slučaju $Z$ protiv Finske navodi sljedeće: „Sud uzima u obzir da je zaštita osobnih podataka, pa tako i medicinskih, od temeljne važnosti za uživanje prava na poštovanje privatnog i obiteljskog života neke osobe, kako je zajamčeno člankom 8 . Konvencije. Poštovanje povjerljivosti podataka o zdravlju je vitalno načelo pravnih sustava svih država potpisnica Konvencije. Ono je od ključne važnosti ne samo u smislu poštovanje privatnosti pacijenta nego i za očuvanje njegovog/njenog povjerenja u medicinsku profesiju i medicinske ustanove uopće. Bez ovakve zaštite, oni kojima je potrebna medicinska pomoć mogli bi se ustručavati od otkrivanja podataka privatne i intimne prirode, što može biti nužno kako bi se dobio odgovarajući tretman, ili čak traženja pomoći uopće, ugrožavajući time i svoje zdravlje, i zdravlje zajednice ukoliko se radi o zaraznim bolestima." U presudi Europskog suda za ljudska prava od 9. listopada 2014. (Konovalova protiv Rusije, zahtjev br. 37873/04) navodi se da prisustvovanje studenata Medicinskog fakulteta porodu, koji su pri tom imali pristup povjerljivim informacijama o zdravstvenom stanju podnositeljice, predstavlja miješanje u njezino pravo na zaštitu privatnog života, slijedom čega je Sud ustanovio kako je došlo do povrede članka 8. Konvencije. Navedeno prema: Pregled prakse europskog suda za ljudska prava, Ured zastupnika Republike Hrvatske pred Europskim sudom za ljudska prava, listopad-prosinac, 2014., str. 29. i 30.; Sud u toč. 40. iste presude ističe da čl. 8. Konvencije uključuje fizički integritet osobe, a s obzirom na to da je tijelo najintimniji aspekt privatnog života pojedinca, i medicinske intervencije, čak i ako su manjeg značaja, predstavljaju zadiranje u privatni život.

34 „Izraz „u skladu sa zakonom“ na temelju članka 8. stavka 2. u načelu zahtijeva, prvo, da sporna mjera ima određeni temelj u domaćem propisu; također se odnosi i na kvalitetu predmetnog propisa koji treba biti u skladu s vladavinom prava te dostupan osobi na koju se odnosi koja mora, štoviše, moći predvidjeti posljedice za sebe, te da mjera mora biti u skladu s vladavinom prava." Točka 80. presude Europskog suda za ljudska prava od 15. siječnja 2015. u predmetu Dragojević protiv Hrvatske (zahtjev br. 68955/11).

35 „Iako je cilj članka 8. u biti zaštititi pojedinca od proizvoljnog miješanja javnih vlasti, on može uključiti mjere koje donose te vlasti, a kojima je cilj osigurati poštivanje privatnog života čak i u sferi odnosa između pojedinaca. Bez obzira analizira li se predmet u smislu pozitivne obaveze države da poduzme razumne i prikladne mjere kako bi zajamčila prava podnositelja zahtjeva na temelju stavka 1. članka 8., ili u smislu miješanja javne vlasti koje treba biti opravdano u skladu sa stavkom 2., primjenjiva načela su dosta slična. U oba se konteksta treba uzeti u obzir pravična ravnoteža koju treba postići između konkurentnih interesa pojedinca i zajednice kao cjeline. Pored toga, čak i u odnosu na pozitivne obveze koje proistječu iz prvog stavka članka 8., u postizanju tražene ravnoteže ciljevi navedeni u drugome stavku mogu biti od određene važnosti.“ Točka 138. presude Europskog suda za ljudska prava od 24. travnja 2014. u predmetu Udovičić protiv Hrvatske (zahtjev br. 27310/09).

36 DRAGIČEVIĆ, Dražen, GUMZEJ, Nina, Obvezno zadržavanje podataka i privatnost, Zbornik Pravnog fakulteta u Zagrebu, vol. 64., br. 1., 2014., str. 44. 
ljudska prava, čine opća načela prava Unije, iako Unija i nije članica iste. ${ }^{37,38}$ Godine 1973. i 1974. Odbor ministara Vijeća Europe usvojio je dvije rezolucije o zaštiti osobnih podataka pozivajući se na članak 8. Europske konvencije o ljudskim pravima, ${ }^{39}$ a 1981. godine za potpisivanje je otvorena Konvencija Vijeća Europe za zaštitu osoba u vezi s automatskom obradom osobnih podataka (ETS broj 108). ${ }^{40}$ Konvencija je sastavljena u Strasbourgu, 28. siječnja

37 Točka 102. presude Općeg suda (šesto vijeće) od 3. prosinca 2015. u predmetu T-343/13 (CN protiv Europskog parlamenta) ECLI:EU:T:2015:926.

38 U literaturi se navodi kako je pristup Europske unije Europskoj konvenciji za zaštitu ljudskih prava i sloboda jedan od najvažnijih razvoja unutar prava EU-a u posljednjih nekoliko godina koji je s jednim mišljenjem Sud EU-a iz prosinca 2014. pretrpio novi udarac. Tako: MEŠKIĆ, Zlatan, Pristupanje Evropske unije Evropskoj konvenciji za zaštitu ljudskih prava, Nova pravna revija, god. 6., vol. 10., 2015., str. 103. Naime, u zahtjevu za mišljenje koji je Sudu Europske unije na temelju članka 218. stavka 11. UFEU-a 4. srpnja 2013. podnijela Europska komisija stoji pitanje: „Je li nacrt sporazuma o pristupanju Europske unije Konvenciji za zaštitu ljudskih prava i temeljnih sloboda, potpisanoj u Rimu 4. studenoga 1950., u skladu s Ugovorima?“" U mišljenju Suda EU-a (Mišljenje 2/13: Mišljenje Suda (puni sastav) od 18. prosinca 2014., Službeni list C 65, 23.02.2015., ECLI:EU:C:2014:2454) stoji: „Sporazum o pristupanju Europske unije Europskoj konvenciji za zaštitu ljudskih prava i temeljnih sloboda nije u skladu s člankom 6. stavkom 2. UEU-a ni s Protokolom EU (br. 8) koji se odnosi na članak 6. stavak 2. Ugovora o Europskoj uniji o pristupanju Unije Europskoj konvenciji za zaštitu ljudskih prava i temeljnih sloboda." U toč. 179. - 181. istog mišljenja Sud EU-a naglašava da s obzirom na to da Unija nije pristupila Europskoj konvenciji za zaštitu ljudskih prava i sloboda, ona nije pravni instrument formalno ugrađen u pravni poredak Unije, te bi zbog pristupanja istoj, poput svakog drugog međunarodnog sporazuma koji je sklopila Unija, na temelju članka 216. stavka 2. UFEU-a, obvezivao institucije Unije i države članice i stoga činio sastavni dio prava Unije. Stoga bi Unija, kao i svaka druga ugovorna stranka, bila podvrgnuta vanjskom nadzoru čiji je cilj poštovanje prava i sloboda koje bi se Unija obvezala poštovati, te bi i njezine institucije, uključujući Sud, bile bi podvrgnute nadzornim mehanizmima predviđenima tom konvencijom i osobito odlukama i presudama Europskog suda za ljudska prava. Zaključuje se da bi, ako bi Europski sud za ljudska prava prilikom svojeg ispitivanja sukladnosti sekundarnog prava s Europskoj konvenciji za zaštitu ljudskih prava i sloboda izabrao vlastito tumačenje među onima koja su moguća, načelo isključive nadležnosti Suda za konačno tumačenje prava Unije bilo bi zacijelo povrijeđeno (toč. 246.). U toč. 1. i 2. stajališta nezavisne odvjetnice Juliane Kokott od 13. lipnja 2014. (Postupak za mišljenje 2/13 pokrenut na zahtjev Europske komisije, ECLI:EU:C:2014:2475) se navodi kako ,planirano pristupanje Europske unije Europskoj konvenciji za zaštitu ljudskih prava i temeljnih sloboda treba dovesti do veće djelotvornosti i veće usklađenosti u poštovanju temeljnih prava u Europi. No, prije svega, Unija će se tim pristupanjem sama podvrgnuti vanjskom nadzoru u pogledu poštovanja standarda temeljnih prava, što se već dugo zahtijeva $\mathrm{s}$ više strana. Na taj način Unija će u konačnici dopustiti da se na nju primjenjuju ista pravila poštovanje kojih ona također uvijek iznova zahtijeva od svojih sadašnjih i budućih država članica. Planirano pristupanje EKLJP-u iznimno je važan projekt ne samo zbog snažne političke poruke nego i zbog ustavnopravne dimenzije. Tim projektom europske institucije bave se uvijek iznova već desetljećima, a i Sud se već po drugi put bavi pravnim aspektima tog projekta."

39 Rezolucija (73) 22 o zaštiti privatnosti pojedinaca vis-à-vis elektroničkih banki podataka u privatnom sektoru, 26. rujna 1973.; Rezolucija (74) 29 o zaštiti privatnosti pojedinaca visà-vis elektroničkih banki podataka u javnom sektoru, 20. rujna 1974., Priručnik o zaštiti podataka 2014., str. 15.

40 Vijeće Europe posvećuje posebnu pozornost problematici zaštite privatnosti i osobnih podataka. Uz prethodno navedene preporuke Vijeće je do danas usvojilo brojne preporuke 
1981. godine, a stupila je na snagu 1. listopada 1985. godine. Dodatni protokol uz Konvenciju za zaštitu osoba u vezi s automatskom obradom osobnih podataka u vezi nadzornih tijela i međunarodne razmjene podataka sastavljen je u Strasbourgu 8. studenog 2001. godine, a stupio je na snagu 1. srpnja 2004. godine. Konvenciju je do sada potpisalo 47 država, a ratificiralo 46 država, dok je Dodatni protokol do sada potpisalo 36 država, od kojih 8 država nije ratificiralo Dodatni protokol.

U članku 4. Konvencije 108 propisana je dužnost stranaka Konvencije. Naime, svaka stranka poduzima u svojem unutrašnjem pravu potrebne mjere kako bi ostvarila temeljna načela za zaštitu podataka sadržana u Konvenciji, a te se mjere moraju poduzeti najkasnije $u$ trenutku njena stupanja na snagu za tu stranku. ${ }^{41}$

Svrha Konvencije broj 108 određena je njezinim člankom 1.: „,svakoj fizičkoj osobi, bez obzira na njezino državljanstvo i boravište, na području svake stranke, osigurati poštovanje njezinih prava i temeljnih sloboda, a osobito njezino pravo na privatnost glede automatizirane obrade osobnih podataka koji se na nju odnose (zaštita podataka)“.

Dodatni protokol predviđa osnivanje neovisnog nadzornog tijela koji će pratiti i nadzirati sukladnost provedbe Konvencije s poduzetim mjerama u unutrašnjem pravu država potpisnica, kao i posredovanje i pokretanje sudskih postupaka u slučaju kršenja odredaba unutrašnjeg prava kojima se štite načela Konvencije i Protokola (čl. 1.) te mogućnost prekograničnog protoka osobnih podataka prema

koje se odnose na zaštitu osobnih podataka. Posljednja takva preporuka usvojena je 13. siječnja 2016.: Recommendation CM/Rec(2016)1 of the Committee of Ministers to Member States on protecting and promoting the right to freedom of expression and the right to private life with regard to network neutrality. U području zaštite osobnih zdravstvenih podataka Vijeće Europe usvojilo je 23. siječnja 1981. preporuku (Recommendation No. R (81) 1 of the Committee of Ministers to Member States on regulations for automated medical data banks) koja je zamijenjena 13. veljače 1997. kada je usvojena nova preporuka o zaštiti medicinskih podataka (Recommendation No. R (97) 5 of the Committee of Ministers to Member States on the protection of medical dana), Pravni instrumenti Vijeće Europe za zaštitu podataka dostupni na: https://www.coe.int/t/dghl/standardsetting/dataprotection/legal_instruments_ en.asp (20.2.2016.).

41 Republika Hrvatska potpisala je Konvenciju 108 5. lipnja 2003. u Strasbourgu, Hrvatski sabor donio je na sjednici 14. travnja 2005. godine Zakon o potvrđivanju Konvencije za zaštitu osoba glede automatizirane obrade osobnih podataka i Dodatnog protokola uz konvenciju za zaštitu osoba glede automatizirane obrade osobnih podataka u vezi nadzornih tijela i međunarodne razmjene podataka (Narodne novine, br. 04/05.). Konvencija i Dodatni protokol stupili su na snagu u odnosu na Republiku Hrvatsku 1. listopada 2005. godine. Temeljni pravni akt koji uređuje zaštitu osobnih podataka o fizičkim osobama te nadzor nad prikupljanjem, obradom i korištenjem osobnih podataka u Republici Hrvatskoj je Zakon o zaštiti osobnih podataka iz 2003. godine. Odbor za zakonodavstvo Hrvatskoga sabora na 23. sjednici održanoj 17. rujna 2012. utvrdio je pročišćeni tekst Zakona o zaštiti osobnih podataka koji obuhvaća Zakon o zaštiti osobnih podataka (Narodne novine, br. 103/03.), Zakon o dopunama Zakona o zaštiti osobnih podataka (Narodne novine, br. 118/06.), Zakon o izmjenama i dopunama Zakona o zaštiti osobnih podataka (Narodne novine, br. 41/08.) i Zakon o izmjenama i dopunama Zakona o zaštiti osobnih podataka (Narodne novine, br. 130/11.). 
primatelju koji nije podložan jurisdikciji stranke Konvencije, uz odgovarajuću razinu zaštite ili zaštitna jamstva koja mogu proizlaziti iz ugovornih odredbi (čl. 2.).

U Povelji Europske unije o temeljnim pravima ${ }^{42}$ navode se temeljna prava, poput prava na poštovanje privatnog i obiteljskog života i prava na zaštitu osobnih podataka, u kojima se odražavaju zajedničke vrijednosti i ustavno nasljeđe Europe. ${ }^{43} \mathrm{U}$ članku 7. Povelje izričito se ističe da ,svatko ima pravo na poštovanje svojeg privatnog i obiteljskog života, doma i komuniciranja“. Pravo na zaštitu osobnih podataka temeljno je pravo priznato člankom 8. Povelje. U članku 8. pod nazivom „Zaštita osobnih podataka“ stoji: „Svatko ima pravo na zaštitu osobnih podataka koji se na njega ili nju odnose. Takvi podaci moraju se obrađivati pošteno, u utvrđene svrhe i na temelju suglasnosti osobe o kojoj je riječ, ili na nekoj drugoj legitimnoj osnovi utvrđenoj zakonom. Svatko ima pravo na pristup prikupljenim podacima koji se na njega ili nju odnose i pravo na njihovo ispravljanje. Poštovanje tih pravila podliježe nadzoru neovisnog tijela. “44 Temeljno pravo na zaštitu osobnih podataka ipak nije apsolutno pravo. ${ }^{45}$

Sud EU-a u svojoj presudi od 8. travnja 2014. u spojenim predmetima C-293/12 i C-594/12 podsjeća na to da zaštita osobnih podataka koja proizlazi iz izričite obveze predviđene u članku 8. stavku 1. Povelje ima osobitu važnost za pravo na poštovanje privatnog života iz njezina članka $7 .{ }^{46}$

Iz prakse Suda EU-a proizlazi da se temeljna prava zajamčena Poveljom moraju poštovati kada nacionalna pravila potpadaju u područje primjene prava

42 Službeni list EU C 303, 12. 12. 2007. Europski parlament, Vijeće Europske unije i Komisija su 7. prosinca 2000. u Nici svečano proglasili Povelju Europske unije o temeljnim pravima (Službeni list C 364, 18.12.2000)., koja danas ima istu pravnu snagu kao Ugovori. Povelja je postala pravno obvezujuća stupanjem na snagu Lisabonskog ugovora 1. prosinca 2009. godine.

43 Europska komisija, Priopćenje za tisak, Temeljna prava: Povelja EU-a sve je važnija i koristi građanima, Bruxelles, 14. travnja 2014.

44 U skladu s člankom 52. stavkom 1. Povelje, svako ograničenje pri ostvarivanju prava i sloboda priznatih njome mora biti predviđeno zakonom i mora poštovati bit tih prava i sloboda te su, podložno načelu proporcionalnosti, ograničenja tih prava i sloboda moguća samo ako su potrebna i ako zaista odgovaraju ciljevima od općeg interesa koje priznaje Unija ili potrebi zaštite prava i sloboda drugih osoba. Prema čl. 53. nijedna odredba Povelje ne smije se tumačiti kao ograničavanje ili nepovoljno utjecanje na ljudska prava i temeljne slobode, na način na koji ih u njihovim područjima primjene priznaju pravo Unije i međunarodno pravo te međunarodni sporazumi čije su stranke Unija ili sve države članice, uključujući Europsku konvenciju za zaštitu ljudskih prava i temeljnih sloboda, te ustavi država članica.

45 „The right to the protection of personal data is not, however, an absolute right, but must be considered in relation to its function in society.", toč. 48. presude Suda EU-a 09. studenog 2010. u spojenim slučajevima Volker und Markus Schecke GbR (C-92/09) and Hartmut Eifert (C-93/09) v Land Hessen, ECLI:EU:C:2010:662.

46 Toč. 53. presude Suda (veliko vijeće) od 8. travnja 2014. (zahtjev za prethodnu odluku koji su uputili High Court of Ireland, Verfassungsgerichtshof - Irska, Austrija) - Digital Rights Ireland Ltd (C-293/12), Kärntner Landesregierung, Michael Seitlinger, Christof Tschohl i dr. (C-594/12) protiv Minister for Communications, Marine and Natural Resources, Minister for Justice, Equality and Law Reform, The Commissioner of the Garda Síochána, Ireland and the Attorney General, ECLI:EU:C:2014:238. 
Unije, odnosno primjena prava Unije uključuje primjenu temeljnih prava zajamčenih Poveljom..$^{47,48}$ Sve institucije i države članice EU-a obvezne su tumačiti Povelju u kontekstu postojeće sudske prakse Europskog suda za ljudska prava. ${ }^{49}$ Institucije EU-a moraju djelovati u skladu s Poveljom u provođenju svih aktivnosti, pa tako i tijekom zakonodavnog procesa, jer u protivnome je moguće da određena mjera (npr. direktiva) bude proglašena nevažećom zbog kršenja temeljnih prava iz Povelje. $^{50}$

Ugovor o funkcioniranju Europske unije u članku 16. (bivši čl. 286. UEZ-a) $)^{51}$ ističe da: „Svatko ima pravo na zaštitu svojih osobnih podataka. Europski parlament i Vijeće, odlučujući u skladu s redovnim zakonodavnim postupkom, utvrđuju pravila o zaštiti pojedinaca s obzirom na obradu osobnih podataka u institucijama, tijelima, uredima i agencijama Unije te u državama članicama kad obavljaju svoje aktivnosti u području primjene prava Unije i pravila o slobodnom kretanju takvih podataka. Poštovanje tih pravila podliježe nadzoru neovisnih tijela.“

47 Presuda Suda EU-a od 16. travnja 2015. u spojenim predmetima (C-446/12) W. P. Willems protiv Burgemeester van Nuth i (C-447/12) H. J. Kooistra protiv Burgemeester van Skarsterlân, ECLI:EU:C:2015:238.

48 Prema čl. 51. Povelje: „Odredbe Povelje odnose se na institucije, tijela, urede i agencije Unije, uz poštovanje načela supsidijarnosti, te na države članice samo kada provode pravo Unije. Oni stoga moraju poštovati prava i držati se načela te promicati njihovu primjenu u skladu sa svojim ovlastima i poštujući ograničenja nadležnosti Unije koje su joj dodijeljene u Ugovorima."

2. Poveljom se ne proširuje područje primjene prava Unije izvan ovlasti Unije, ne uspostavlja se nova ovlast ni zadaća za Uniju niti se mijenjaju ovlasti i zadaće kako su utvrđene Ugovorima.

49 Izvješće Komisije Europskom parlamentu, Vijeću, Europskom gospodarskom i socijalnom odboru i Odboru regija, Izvješće o primjeni Povelje EU-a o temeljnim pravima za 2014. $\operatorname{COM}(2015) 191$ final, Bruxelles, 8.5.2015., str. 12.

50 Tako je primjerice Sud (Veliko vijeće) u ranije navedenoj presudi od 8. travnja 2014. u spojenim predmetima C-293/12 i C-594/12 odlučio da je Direktiva 2006/24/EZ Europskog parlamenta i Vijeća od 15. ožujka 2006. o zadržavanju podataka dobivenih ili obrađenih u vezi s pružanjem javno dostupnih elektroničkih komunikacijskih usluga ili javnih komunikacijskih mreža i o izmjeni Direktive 2002/58/EZ (Službeni list L 105, 13. 04. 2006.) nevaljana zbog kršenja temeljnih prava na privatnost i zaštitu osobnih podataka zajamčenih člancima 7 . i 8. Povelje. Prema navedenoj presudi usvajanjem Direktive 2006/24 zakonodavac Unije prekoračio je granice koje nameće poštovanje načela proporcionalnosti s obzirom na članak 7., članak 8. i članak 52. stavak 1. Povelje., Ibid., str. 3.

51 Vidi: Treaty of Lisbon amending the Treaty on European Union and the Treaty establishing the European Community (Official Journal of the European Union C 306, 17.12.2007.); Lisabonski ugovor Europske unije - Konsolidirani tekst Ugovora o Europskoj uniji (Maastricht, 1992.) - Konsolidirani tekst Ugovora o funkcioniranju Europske unije (Rim, 1957.): protokoli, prilozi i izjave (glavni redaktor hrvatskoga prijevoda Davorin Rudolf), Adrias, No. 16., Zagreb - Split, 2009.; ĆAPETA, Tamara, Europska unija po Lisabonskom ugovoru, Hrvatska javna uprava, god. 10., br. 1., 2010., str. 35. - 47. 


\subsection{Direktiva EU-a o zaštiti podataka}

Prošlo je dvadeset godina od usvajanja iznimno važnog pravnog akta institucija Europske unije koji će značajno ojačati temeljna prava pojedinca na zaštitu podataka i postaviti čvrste temelje za izgradnju i moderniziranje područja zaštite podataka. ${ }^{52}$ Taj pravni instrument EU-a daje sadržaj i jača načela iz Konvencije Vijeća Europe za zaštitu pojedinaca u vezi s automatskom obradom osobnih podataka iz 1981. godine. Riječ je o Direktivi 95/46/EZ Europskog parlamenta i Vijeća od 24. listopada 1995 o zaštiti pojedinaca u vezi s obradom osobnih podataka i o slobodnom protoku takvih podataka (dalje u tekstu: Direktiva o zaštiti podataka ili Direktiva 95/46/EZ). ${ }^{53,54}$

Direktivom 95/46/EZ je utvrđen opći okvir za zaštitu osobnih podataka u Europskoj uniji. ${ }^{55}$ Cilj Direktive o zaštiti osobnih podataka je zaštita temeljnih prava i sloboda fizičkih osoba, ${ }^{56}$ a posebno prava na privatnost u vezi s obradom osobnih podataka (čl. 1.). Ona jamči visoku razinu zaštite temeljnih prava i sloboda fizičkih

52 Zaštita pojedinaca s obzirom na obradu osobnih podataka od strane institucija Unije zajamčena je Uredbom (EZ) br. 45/2001 Europskog parlamenta i Vijeća od 18. prosinca 2000. o zaštiti pojedinaca pri obradi osobnih podataka od strane institucija i tijela Zajednice te o slobodnome protoku takvih podataka (Službeni list L 8, 12. 01. 2001.). Ova Uredba ne utječe na prava i obveze država članica iz Direktive 95/46. U skladu s Uredbom 45/2001, institucije i tijela osnovana Ugovorima ili na temelju Ugovora o osnivanju Europskih zajednica dužni su štititi temeljna prava i slobode fizičkih osoba, a posebno njihovo pravo na privatnost pri obradi osobnih podataka, te ne smiju ograničiti niti zabraniti slobodan protok osobnih podataka među njima ili prema primateljima, i to sukladno nacionalnome pravu država članica koje provode Direktivu 95/46/EZ. Uredba se 45/2001 primjenjuje na obradu osobnih podataka u svim institucijama i tijelima Unije pod uvjetom da se takva obrada provodi $u$ okviru obavljanja djelatnosti koje su u potpunosti ili djelomično u području primjene prava EU-a. Također, ova se Uredba primjenjuje na obradu osobnih podataka u potpunosti ili djelomično putem automatskih sredstava, kao i na obradu osobnih podataka ostalim sredstvima koja čine dio sustava datoteka ili su namijenjena da budu dio sustava datoteka.

53 Službeni list EU L 281, 23. 11. 1995.

54 Direktiva 97/66/EZ Europskog parlamenta i Vijeća od 15. prosinca 1997. o obradi osobnih podataka i zaštiti privatnosti u području telekomunikacija (Službeni list EU L 24, 30. 01. 1998.) prenijela je načela navedena u Direktivi 95/46/EZ u posebna pravila za područje telekomunikacija. Ova je Direktiva stavljena izvan snage i zamijenjena Direktivom 2002/58/ EZ Europskog parlamenta i Vijeća od 12. srpnja 2002. o obradi osobnih podataka i zaštiti privatnosti u području elektroničkih komunikacija (Službeni list EU L 201, 12. 07. 2002.). Vidi: četvrtu uvodnu izjavu Preambule navedene Direktive.

55 Toč. 19. Preambule Uredbe Komisije (EU) br. 611/2013 od 24. lipnja 2013. o mjerama koje se primjenjuju na obavješćivanje o povredama osobnih podataka u skladu s Direktivom 2002/58/EZ Europskog parlamenta i Vijeća o privatnosti i elektroničkim komunikacijama, službeni list L 173, 26. 06. 2013.

56 „Iz članka 1., kao i uvodnih izjava 2. i 10., Direktive 95/46 proizlazi da ona nastoji ne samo zajamčiti učinkovitu i potpunu zaštitu temeljnih prava i sloboda fizičkih osoba, a posebno temeljnog prava na poštovanje privatnosti u vezi s obradom osobnih podataka, nego i visoku razinu zaštite tih temeljnih prava i sloboda“, Presuda Suda Europske unije od 6. listopada 2015. u predmetu C-362/14 (Schrems) toč. 39. 
osoba, a posebno njihova prava na privatnost $u$ vezi s obradom osobnih podataka. ${ }^{57}$ Direktiva o zaštiti podataka ima za cilj i uklanjanje zapreka slobodnom protoku tih podataka, kako je navedeno u uvodnim izjavama 25. i $41 .^{58}$

Pojam „osobnih podataka“ definiran je u članku 2. točki (a) Direktive 95/46/ EZ kao „bilo koji podaci koji se odnose na utvrđenu fizičku osobu ili fizičku osobu koju se može utvrditi ("osoba čiji se podaci obrađuju"); ${ }^{59}$ osoba koja se može utvrditi je osoba čiji je identitet moguće utvrditi, izravno ili neizravno, a posebno navođenjem identifikacijskog broja ili jednog ili više činitelja značajnih za njegov fizički, fiziološki, mentalni, gospodarski, kulturni ili socijalni identitet, dok "obrada osobnih podataka” (čl. 2. toč. b.) znači „bilo koji postupak ili skup postupaka koji se provode nad osobnim podacima, bilo automatskim putem ili ne, kao što je prikupljanje, snimanje, organiziranje, pohrana, prilagođavanje ili mijenjanje, vraćanje, obavljanje uvida, uporaba, otkrivanje prijenosom i širenjem, ili stavljanje na raspolaganje drugim načinom, poravnavanje ili kombiniranje, blokiranje, brisanje ili uništavanje“.

Članak 3. pod naslovom „Područje primjene“ određuje da se Direktiva 95/46/ EZ primjenjuje na osobne podatke koji se u cijelosti ili djelomično obrađuju automatskim putem i na obradu podataka koja nije automatska, a koja čini dio sustava arhiviranja ili će činiti dio sustava arhiviranja. Istim člankom određeno je da se Direktiva 95/46/EZ ne primjenjuje na obradu osobnih podataka tijekom aktivnosti

57 Presuda Suda EU-a od 1. listopada 2015. godine u predmetu C-230/14 (Weltimmo s. $r$. o. protiv Nemzeti Adatvédelmi és Információszabadság Hatóság): „... 25. S obzirom na to da je cilj Direktive 95/46 učinkovita i potpuna zaštita temeljnih prava i sloboda fizičkih osoba, a posebno prava na privatnost u vezi s obradom osobnih podataka, .... 26. Kako bi se postigao taj cilj i kako bi se izbjeglo to da pojedinac bude lišen zaštite koju mu jamči ta direktiva, uvodna izjava 18. navedene direktive propisuje da se bilo kakva obrada osobnih podataka u Uniji mora izvršavati u skladu sa zakonodavstvom jedne od država članica i da obradu za koju je odgovoran nadzornik s poslovnim nastanom u državi članici treba urediti zakonodavstvom te države."

58 „25. budući da se načela zaštite $\mathrm{s}$ jedne strane moraju odraziti u obvezama koje su preuzele osobe, javna tijela, poduzetnici, agencije ili druga tijela nadležna za obradu, posebno u vezi s kvalitetom podataka, tehničkom sigurnošću, obavješćivanjem nadzornog tijela te okolnostima pod kojima se obrada može provoditi, i s druge strane, pravima koja imaju pojedinci čiji su podaci predmet obrade da ih se izvijesti da je obrada u tijeku, da imaju uvid u podatke, da zatraže ispravak i čak da se usprotive obradi pod nekim okolnostima; 41. budući da svaka osoba mora biti u mogućnosti ostvariti pravo na pristup podacima koji se na nju odnose, a koji se obrađuju kako bi posebno provjerila točnost podataka te zakonitost obrade; budući da iz istih razloga svaka osoba čiji se podaci obrađuju također ima pravo znati logiku u automatskoj obradi podataka, barem u slučaju automatskih odluka iz članka 15. stavka 1. ove Direktive; budući da to pravo ne smije utjecati na poslovne tajne ili intelektualno vlasništvo te posebno na autorska prava kojim se štiti programska oprema; budući da ta pitanja međutim ne smiju dovesti do toga da se osobi čiji se podaci obrađuju odbiju svi podaci.“

$59, \ldots$ tumačenje pojma „osobnih podataka“ u smislu Direktive 95/46 ne proizlazi samo iz teksta njezina članka 2. točke (a) nego je potvrđeno i njezinim ciljem i strukturom.“, Toč. 41. presude Suda EU-a od 17. srpnja 2014. u spojenim predmetima C-141/12 Y. S. protiv Minister voor Immigratie, Integratie en Asiel i C-372/12 Minister voor Immigratie, Integratie en Asiel protiv M., S., ECLI:EU:C:2014:2081. 
koja je izvan područja primjene prava Unije, kao što je predviđeno u glavama V. i VI. Ugovora o Europskoj uniji i u svakom slučaju na postupke obrade koji se odnose na javnu sigurnost, obranu, nacionalnu sigurnost (uključujući gospodarsku dobrobit države kada se operacija obrade odnosi na pitanja nacionalne sigurnosti) i aktivnosti države u području kaznenog prava, te na obradu osobnih podataka koju provodi fizička osoba tijekom aktivnosti isključivo osobne ili domaće naravi. Prema praksi Suda EU-a navedeno odstupanje mora se tumačiti strogo. ${ }^{60}$

Direktivom 95/46/EZ je predviđeno osobito široko teritorijalno područje njezine primjene, koje je propisano člankom 4. Prema stavku 1. točki (a) navedenog članka svaka država članica na obradu osobnih podataka primjenjuje nacionalne propise koje donese u skladu s Direktivom kada se obrada provodi u okviru aktivnosti poslovnog nastana nadzornika na području države članice. Kada taj nadzornik ima poslovni nastan na području nekoliko država članica, on mora poduzeti potrebne mjere kako bi osigurao da svaki od tih poslovnih nastana ispunjava obveze propisane važećim nacionalnim pravom. ${ }^{61}$ Propisujući osobito široko područje teritorijalne primjene zakonodavac EU-a je želio izbjeći to da pojedinac bude lišen zaštite koju mu jamči direktiva kao i zaobilaženje te zaštite. ${ }^{62}$

U Glavi II. Direktive 95/46/EZ pod naslovom „Opća pravila o zakonitosti obrade osobnih podataka" sadržana su načela koja se odnose na kvalitetu podataka (čl. 6.) i mjerila za zakonitost obrade podataka (čl. 7.). Svaka obrada osobnih podataka treba biti u skladu s tim načelima, odnosno mjerilima.

Sukladno članku 8. stavku 1. Direktive 95/46/EZ obrada podataka u vezi sa zdravljem izričito je zabranjena. ${ }^{63}$ Navedenim je člankom određeno da države članice zabranjuju obradu osobnih podataka kojima se otkriva rasno ili etničko podrijetlo, politička mišljenja, vjerska ili filozofska uvjerenja, članstvo u sindikatu i obrada podataka u vezi sa zdravljem ili spolnim životom. Ovo pravilo međutim ima određene iznimke. ${ }^{64}$ Jedna od njih je sadržana u odredbi članka 8. stavka 3. koja

60 Vidi: C-212/13, František Ryněs protiv Úřad pro ochranu osobních údajů, ECLI:EU: C:2014:2428.

61 „Članak 4. stavak 1. točku (a) Direktive 95/46/EZ Europskog parlamenta i Vijeća od 24. listopada 1995. o zaštiti pojedinaca u vezi s obradom osobnih podataka i o slobodnom protoku takvih podataka treba tumačiti na način da omogućuje primjenu zakonodavstva koje se odnosi na zaštitu osobnih podataka države članice koja je različita od one u kojoj je nadzornik obrade tih podataka registriran ako on putem stabilnih dogovora na području te države članice provodi, čak i najmanju, efektivnu i stvarnu aktivnost u okviru koje se ta obrada provodi.“, Presuda Suda EU-a od 1. listopada 2015. godine u predmetu C-230/14 (Weltimmo s. r. o. protiv Nemzeti Adatvédelmi és Információszabadság Hatóság).

62 Toč. 54. presude Suda EU-a od 13. svibnja 2014. u predmetu C-131/12 Google Spain SL, Google Inc. protiv Agencia Española de Protección de Datos (AEPD), Mario Costeja González, ECLI:EU:C:2014:317.

63 „Reference to the fact that an individual has injured her foot and is on half-time on medical grounds constitutes personal data concerning health within the meaning of Article 8(1) of Directive 95/46.“ Presuda Suda EU- a od 6. studenog 2003. u predmetu C-101/01, ECLI:EU:C:2003:596.

64 Čl. 6. Konvencije 108 Vijeća Europe glasi: „Osobni podaci koji otkrivaju rasno podrijetlo, politička mišljenja, vjerska ili druga uvjerenja, kao i osobni podaci koji se tiču zdravlja 
glasi: „Stavak 1. ovog članka ne primjenjuje se kada je obrada podataka potrebna u svrhe preventivne medicine, medicinske dijagnoze, zdravstvene skrbi ili liječenja ili upravljanja zdravstvenim službama, te kada te podatke obrađuje zdravstveni radnik koji na temelju nacionalnog zakonodavstva ili pravila koje donesu nacionalna nadležna tijela podliježe obvezi čuvanja profesionalne tajne ili druga osoba koja također podliježe istoj obvezi čuvanja tajne.“

U točki 33. i 34. uvodne izjave Direktive 95/46/EZ se ističe da se: ,... podaci koji po svojoj prirodi mogu prekršiti temeljne slobode ili privatnost ne smiju obrađivati ako osoba čiji se podaci obrađuju nije dala svoju izričitu suglasnost; budući da međutim se odstupanja od ove zabrane moraju izričito navesti za posebne potrebe, posebno kada obradu podataka u zdravstvene svrhe provodi osoba na koju se odnosi zakonska obveza čuvanja profesionalne tajne ili kada neke udruge ili ustanove čija je svrha omogućavanje ostvarenja temeljnih sloboda tijekom obavljanja zakonitih aktivnosti;““ kao i da: „države članice također moraju biti ovlaštene, kada je to opravdano na temelju važnog javnog interesa, za odstupanje od zabrane obrađivanja osjetljivih kategorija podataka kada to opravdavaju važni razlozi javnog interesa na područjima kao što je javno zdravstvo i socijalna zaštita - posebno kako bi se osiguralo da kvaliteta i isplativost postupaka koji se koriste za rješavanje zahtjeva za ostvarenje pogodnosti i usluga iz sustava zdravstvenog osiguranja - znanstveno istraživanje i vladine statistike; budući da im je dužnost da pruže konkretnu i odgovarajuću zaštitu temeljnih prava i privatnosti pojedinaca“. Prema ustaljenoj sudskoj praksi Suda EU-a zaštita prava na poštovanje privatnog života u svakom slučaju zahtijeva da su odstupanja i ograničenja u zaštiti osobnih podataka u granicama onog što je strogo nužno. ${ }^{65}$

\subsection{Direktiva EU o pravima pacijenata u prekograničnoj zdravstvenoj zaštiti}

Uspješan razvoj prekograničnih zdravstvenih usluga ovisi i o povjerenju korisnika tih usluga (pacijenata) da njihova privatnost neće biti ugrožena, odnosno da će podatci o njegovom zdravlju biti na odgovarajući način korišteni i zaštićeni.

Jedno od područja koje dijelom dotiče Direktiva 2011/24/EU o primjeni prava pacijenata u prekograničnoj zdravstvenoj zaštiti (u daljnjem tekstu: Direktiva 2011/24/EU) ${ }^{66}$ je i prekogranični prijenos i zaštita osobnih podataka o zdravlju

ili spolnog života, ne mogu se automatizirano obrađivati ako unutarnje pravo ne predviđa primjerenu zaštitu. Isto se primjenjuje na osobne podatke koji se odnose na kaznene presude.“

65 Toč. 52. presude Suda (Veliko vijeće) od 8. travnja 2014. (zahtjev za prethodnu odluku koji su uputili High Court of Ireland, Verfassungsgerichtshof - Irska, Austrija) - Digital Rights Ireland Ltd (C-293/12), Kärntner Landesregierung, Michael Seitlinger, Christof Tschohl i dr. (C-594/12) protiv Minister for Communications, Marine and Natural Resources, Minister for Justice, Equality and Law Reform, The Commissioner of the Garda Siochána, Ireland and the Attorney General, ECLI:EU:C:2014:238.

66 Službeni list L 88, 4. 4. 2011. Direktiva 2011/24/EU je potpisana 9. ožujka 2011. u Strasbourgu, a stupila je na snagu dvadesetog dana od dana objave u Službenom listu Europske unije. Države članice trebale su prenijeti Direktivu 2011/24/EU u nacionalna zakonodavstva do 25. listopada 2013. godine. 
pacijenata. Ovom Direktivom utvrđuju se pravila za olakšavanje pristupa sigurnoj i kvalitetnoj prekograničnoj zdravstvenoj zaštiti te promiče suradnja u području zdravstvene zaštite između država članica uz potpuno poštovanje nacionalnih nadležnosti pri organizaciji i pružanju zdravstvene zaštite. ${ }^{67}$

Direktiva 2011/24/EU se primjenjuje ne dovodeći u pitanje Direktivu 95/46/EZ i Direktivu 2002/58/EZ Europskog parlamenta i Vijeća od 12. srpnja 2002. o obradi osobnih podataka i zaštiti privatnosti u području elektroničkih komunikacija. ${ }^{68}$

Kako stoji u točki 25. Preambule Direktive 2011/24/EU: „Osiguranje kontinuiteta prekogranične zdravstvene zaštite ovisi o prijenosu osobnih podataka o zdravlju pacijenata. Potrebno je omogućiti protok osobnih podataka iz jedne države članice u drugu, ali istodobno treba zaštititi temeljna prava osoba. Direktivom 95/46 ... utvrđuje se pravo osoba na pristup svojim osobnim podacima o zdravlju, na primjer podacima u svojim zdravstvenim kartonima koji sadrže podatke poput dijagnoza, rezultata pregleda, ocjena liječnika i svih obavljenih postupaka liječenja ili intervencija. Te bi odredbe trebalo primjenjivati i u kontekstu prekogranične zdravstvene zaštite.“ Prema članku 4. stavku 2(e)(f) država članica liječenja osigurava da je zaštićeno temeljno pravo na privatnost u vezi s obradom osobnih podataka u skladu s nacionalnim mjerama kojima se provode propisi Unije o zaštiti osobnih podataka, posebno Direktiva 95/46/EZ, te da zbog osiguranja kontinuiteta skrbi pacijenti koji su primili terapiju imaju pravo na pisani ili elektronički zdravstveni karton te terapije i dobivanje barem jednoga primjerka toga kartona u skladu s i podložno nacionalnim mjerama kojima se provode odredbe Unije o zaštiti osobnih podataka, posebno Direktiva 95/46/EZ i 2002/58/EZ.

Države članice liječenja osiguravaju da se informacije o pravu na obavljanje djelatnosti zdravstvenih stručnjaka navedenih u nacionalnim ili lokalnim registrima uspostavljenim na njihovom državnom području na zahtjev stave na raspolaganje nadležnim tijelima drugih država članica za potrebe prekogranične zdravstvene

67 Opširnije o Direktivi 2011/24/EU: PEETERS, Mark, Free Movement of Patients: Directive 2011/24 on the Application of Patients' Rights in Cross-Border Health care, European Journal of Health Law, vol. 19., 2012., str. 29. - 60.; SOKOL Tomislav, MINTAS HODAK Ljerka, ABRAMOVIĆ, Ana, Patient Mobility Directive: One Step Forward or Two Steps Back for Cross-Border Healthcare, Croatian Yearbook of European Law and Policy, vol. 8., no. 8., 2012., str. 143. - 173.; ČOLAKOVIĆ, Maja, BEVANDA, Marko, Ostvarenje zdravstvene zaštite u Bosni i Hercegovini u svjetlu Direktive 2011/24/EU o primjeni prava pacijenata u prekograničnoj zdravstvenoj skrbi Zbornik radova: II Međunarodna konferencija Bosna i Hercegovina i euroatlantske integracije - Trenutni izazovi i perspektive, god. 2, br. 2, tom I, Pravni fakultet Univerziteta u Bihaću, Centar za društvena istraživanja Internacionalnog Burč univerziteta, Bihać, 2014., str. 361. - 382.

68 „Pravila o međunarodnim prijenosima podataka utvrđena Direktivom 95/46/EZ temelje se na jasnoj razlici između, s jedne strane, prijenosa trećim zemljama koje osiguravaju odgovarajuću razinu zaštite (članak 25. Direktive) te, s druge strane, prijenosa trećim zemljama za koje je utvrđeno da ne osiguravaju odgovarajuću razinu zaštite (članak 26. Direktive).“ Komunikacija Komisije Europskom parlamentu i Vijeću o prijenosu osobnih podataka iz EU-a u Sjedinjene Američke Države u skladu s Direktivom 95/46/EZ nakon presude Suda u predmetu C-362/14 (Schrems), $\operatorname{COM(2015)~} 566$ final, Bruxelles, 06.11.2015. 
zaštite u skladu s poglavljima II. i III. i s nacionalnim mjerama kojima se provode odredbe Unije o zaštiti osobnih podataka, posebno Direktiva 95/46/EZ i 2002/58/ EZ te s načelom pretpostavke nedužnosti (čl. 10. st. 4. Direktive 2011/24/EU).

Prema članku 14. Direktive 2011/24/EU Unija podupire i olakšava suradnju i razmjenu informacija među državama članicama koje djeluju u sklopu dobrovoljne mreže koja povezuje državna tijela odgovorna za e-zdravstvo, a koja su imenovale države članice. Ciljevi mreže e-zdravstva su: djelovanje u smjeru pružanja održivih ekonomskih i socijalnih naknada europskih sustava e-zdravstva te usluga $i$ interoperabilnih aplikacija radi postizanja visoke razine povjerenja $i$ sigurnosti, unaprjeđenja kontinuiteta zdravstvene zaštite i osiguranja pristupačnosti sigurne i kvalitetne zdravstvene zaštite; izrada smjernica o netaksativnom popisu podataka koje treba uključiti u sažetke o pacijentima i koje zdravstveni stručnjaci mogu međusobno razmjenjivati kako bi se omogućio kontinuitet prekogranične zdravstvene zaštite i sigurnosti pacijenata; i učinkovitim metodama za omogućavanje korištenja medicinskih podataka za javno zdravstvo i istraživanje; te potpora državama članicama u razvoju zajedničkih mjera za identifikaciju i utvrđivanje vjerodostojnosti radi pojednostavljenja mogućnosti prenošenja podataka u prekograničnoj zdravstvenoj zaštiti. Navedeni ciljevi poduzimaju se uz dužno poštovanje načela zaštite podataka kako je navedeno posebno u direktivama 95/46/ EZ i 2002/58/EZ.

\subsection{Uredba EU-a o kliničkim ispitivanjima lijekova}

Iznimno važan zakonodavni akt EU-a u području zaštite osobnih podataka u zdravstvenom sektoru je Uredba EU-a o kliničkim ispitivanjima lijekova ${ }^{69,70} \mathrm{U}$ prvoj točki Preambule i članku 3. navedene Uredbe izričito se navodi da se tijekom provođenja kliničkog ispitivanja trebaju zaštititi prava, zdravlje, dostojanstvo i dobrobit ispitanika, te da interesi ispitanika uvijek trebaju imati prednost pred svim drugim interesima. Dakle, kliničko ispitivanje koje se provodi u EU može se provesti samo ako su prava ispitanika na fizički i mentalni integritet, privatnost i zaštitu podataka koji se odnose na njih zaštićena u skladu s Direktivom 95/46/EZ (čl. 28., st. 1(d)).

69 Uredba (EU) br. 536/2014 Europskog parlamenta i Vijeća od 16. travnja 2014. o kliničkim ispitivanjima lijekova za primjenu kod ljudi te o stavljanju izvan snage Direktive 2001/20/EZ (Tekst značajan za EGP) (Službeni list EU L 158, 27. 05. 2014.).

70 Prema čl. 99. ova Uredba stupa na snagu dvadesetog dana od dana objave u Službenom listu Europske unije. Primjenjuje se šest mjeseci nakon objave obavijesti navedene u članku 82. stavku 3., ali u svakom slučaju ne ranije od 28. svibnja 2016. Čl. 82. glasi: „1. Agencija, u suradnji s državama članicama i Komisijom sastavlja funkcionalne specifikacije za portal EU-a i bazu podataka EU-a, zajedno s vremenskim okvirom za njihovu provedbu. 2. Upravni odbor Agencije na temelju neovisnog revizijskog izvješća obavješćuje Komisiju o tome kada je utvrdio da su portal EU-a i baza podataka EU-a potpuno funkcionalni i sustavi ispunjavaju funkcionalne specifikacije sastavljene u skladu sa stavkom 1. 3. Komisija objavljuje obavijest u Službenom listu Europske unije kada bude smatrala da su uvjeti iz stavka 2. ispunjeni.“ 
Sukladno tome, Uredbom (EU) 563/2014 se poštuju temeljna prava i uzimaju u obzir načela koja su posebno priznata Poveljom EU-a o temeljnim pravima, posebno ljudsko dostojanstvo, integritet osobe, prava djeteta, poštovanje privatnog i obiteljskog života, zaštita osobnih podataka te umjetnička i znanstvena sloboda (točka 83. Preambule).

Direktiva 95/46 se primjenjuje na obradu osobnih podataka provedenu u državama članicama pod nadzorom nadležnih tijela država članica u okviru ove Uredbe, posebno nezavisnih javnih tijela koja imenuju države članice i Uredbe 45/2001 koja se primjenjuje na obradu osobnih podataka koju provode Komisija i Agencija u okviru ove Uredbe pod nadzorom Europskog nadzornika za zaštitu podataka. Ti instrumenti jačaju prava na zaštitu osobnih podataka te obuhvaćaju pravo na pristup, ispravak i povlačenje, kao i određivanje situacija kada se može nametnuti ograničenje na ta prava. S ciljem poštovanja prava na zaštitu osobnih podataka, istodobno štiteći konzistentnost i pouzdanost podataka iz kliničkih ispitivanja koji se koriste $\mathrm{u}$ znanstvene svrhe te sigurnost ispitanika koji sudjeluju u kliničkim ispitivanjima, primjereno je osigurati da povlačenje informiranog pristanka, ne dovodeći u pitanje Direktivu 95/46, ne utječe na rezultate aktivnosti koje se provode, poput pohrane i upotrebe podataka dobivenih na temelju informiranog pristanka prije povlačenja. ${ }^{71}$

U točki 66. i 67. preambule Uredba EU-a o kliničkim ispitivanjima lijekova ističe se važnost uspostave baze podataka EU-a o kliničkim ispitivanjima (engl. Clinical Trials Register $)^{72}$ dostupne putem portala EU-a u koje se ne smiju zabilježiti nikakvi osobni podatci ispitanika koji sudjeluju u kliničkom ispitivanju. ${ }^{73}$ Nadalje se ističe da te informacije trebaju biti javne (osim ako ne postoje određeni razlozi za neobjavljivanje nekih informacija kako bi se zaštitilo pravo pojedinca na privatni život i pravo na zaštitu osobnih podataka, koji su utvrđeni člancima 7. i 8. Povelje) i doprinijeti zaštiti javnog zdravlja i poticanju inovacijskog kapaciteta europskog medicinskog istraživanja istodobno prepoznajući legitimne ekonomske interese naručitelja ispitivanja.

\subsection{Praksa Suda Europske unije u području zaštite osobnih podataka}

Kako je uvodno navedeno, važnost kako temeljnog prava na poštovanje privatnog života, zajamčenog u članku 7. Povelje, tako i temeljnog prava na zaštitu osobnih podataka, zajamčenog u članku 8. Povelje, naglašava i sudska praksa Suda EU-a. Poznato je da je Sud EU-a najviši autoritet za tumačenje prava EU-a koja je obvezujuća za nacionalne sudove država članica. ${ }^{74}$ Stoga i presude Suda EU-a

71 Toč. 76. uvodne izjave Uredbe (EU) 563/2014.

72 EU Clinical Trial Register - https://www.clinicaltrialsregister.eu. Vidi: https://eudract.ema. europa.eu/ (28.1.2016.).

73 Vidi čl. 81. i 82. Uredbe (EU) 563/2014.

74 RODIN, Siniša, Hrvatski sudac između prava EU i nacionalnog prava, Informator, br. 5871, Zagreb, 2010., str. 5. i 6., RODIN, Siniša, Konstitucionalizacija općih načela prava u novijoj praksi Europskog suda, Informator, br. 5847, Zagreb, 2010., str. 1. i 2. 
u području zaštite osobnih podataka (u vezi sa zdravljem) imaju veliku važnost za nacionalne sudove država članica, ali i za sudove država koje teže pristupanju Uniji.

Presudom Suda EU-a od 6. listopada 2015. u predmetu C-362/14 (Schrems) $)^{75}$ ponovno se potvrđuje važnost temeljnog prava na zaštitu osobnih podataka, kako je utvrđeno u Povelji EU-a o temeljnim pravima, uključujući slučajeve kad se takvi podatci prenose izvan EU-a. ${ }^{76}$

Prema praksi Suda EU-a članak 2. točku (a) Direktive 95/46/EZ kojom je definiran pojam „osobnog podatka“ treba tumačiti na način da „upisnik radnog vremena, poput onoga u glavnom postupku, koji za svakog radnika pokazuje početak i završetak radnog vremena, kao i prekide ili odgovarajuće pauze, ulazi u pojam „osobnih podataka“, u smislu te odredbe.“ Direktiva 95/46 dopušta, u načelu, obradu samo onih podataka za koje je odnosna osoba dala svoju suglasnost, ali ona se ne primjenjuje na obradu osobnih podataka koju provodi fizička osoba tijekom aktivnosti isključivo osobne ili domaće naravi. ${ }^{77}$

Sukladno ustaljenoj sudskoj praksi, zaštita temeljnog prava na privatni život zajamčena člankom 7. Povelje Europske unije o temeljnim pravima zahtijeva da su odstupanja i ograničenja u zaštiti osobnih podataka u granicama onog što je strogo nužno. U presudi Suda EU-a od 11. prosinca 2014. u predmetu C-212/13 (Ryneš) se navodi: „U mjeri u kojoj se odredbe Direktive 95/46, uređujući obradu osobnih podataka koji mogu povrijediti temeljne slobode i posebno pravo na privatnost, nužno moraju tumačiti u svjetlu temeljnih prava koja prema ustaljenoj sudskoj praksi čine sastavni dio općih načela prava čije poštovanje Sud osigurava i koja su upisana u Povelju, odstupanje predviđeno člankom 3. stavkom 2. mora se strogo tumačiti.“"78

Dakle, prema praksi Suda EU-a odstupanje i ograničenje u zaštiti podataka mora se tumačiti strogo. Tako Sud EU-a određuje: „Članak 3. stavak 2. drugi podstavak Direktive 95/46/EZ Europskog parlamenta i Vijeća od 24. listopada 1995. o zaštiti pojedinaca u vezi s obradom osobnih podataka i o slobodnom kretanju takvih podataka treba tumačiti u smislu da korištenje sustava nadzornih kamera, zahvaljujući kojem je snimljen videozapis pohranjen na uređaj za kontinuirano snimanje kao što je tvrdi disk, koji je fizička osoba ugradila u svoju obiteljsku kuću u cilju zaštite imovine, zdravlja i života vlasnika kuće te taj sustav nadzire i javni prostor, ne predstavlja obradu podataka koja se provodi za obavljanje isključivo osobnih ili domaćih aktivnosti u smislu te odredbe."“79

75 C-362/14, Maximillian Schrems protiv Data Protection Commissioner, uz sudjelovanje: Digital Rights Ireland Ltd, ECLI:EU:C:2015:650.

76 Komunikacija Komisije Europskom parlamentu i Vijeću o prijenosu osobnih podataka iz EU-a u Sjedinjene Američke Države u skladu s Direktivom 95/46/EZ nakon presude Suda u predmetu C-362/14 (Schrems), COM(2015) 566 final, Bruxelles, 6.11.2015.

77 Sud Europske unije, Priopćenje za medije br. 175/14, u Luxembourgu 11. prosinca 2014., presuda u predmetu C-212/13 František Ryneš / Úráa pro ochranu osobnich údaju.

78 Toč. 29., C-212/13, František Ryneš protiv Úřad pro ochranu osobnich údajü, ECLI:EU: C:2014:2428.

79 Presuda u predmetu C-212/13 František Ryneš / Úřad pro ochranu osobnich údajů. 
Zaštita temeljnog prava na poštovanje privatnosti podrazumijeva osobito to da ta osoba može biti sigurna da su osobni podatci koji se odnose na nju točni i obrađeni na zakoniti način. ${ }^{80} \mathrm{U}$ presudi Suda EU-a od 1. listopada 2015. u predmetu C-201/14 (Bara i drugi) stoji: „U skladu s odredbama Glave II. Direktive 95/46, naslovljene „Opća pravila o zakonitosti obrade osobnih podataka“, osim odstupanja predviđenih u članku 13. te Direktive, svaka obrada osobnih podataka treba s jedne strane biti u skladu s načelima koja se odnose na kvalitetu podataka navedenima u članku 6. spomenute Direktive i, s druge strane, odgovarati na jedno od načela koja se odnose na zakonitost obrade podataka navedenih u članku 7. te iste Direktive. Nadalje se ističe da, ,članke 10., 11. i 13. Direktive 95/46/EZ Europskog parlamenta i Vijeća od 24. listopada 1995. o zaštiti pojedinaca u vezi s obradom osobnih podataka i o slobodnom protoku takvih podataka treba tumačiti na način da su im protivne nacionalne mjere, kao što su one o kojima je riječ u glavnom postupku, koje tijelu javne uprave države članice dopuštaju da osobne podatke proslijedi nekom drugom tijelu javne uprave te da ih naknadno obradi a da dotične osobe nisu bile obaviještene ni o tom prosljeđivanju ni o toj obradi. “681

Prema praksi Suda EU-a članak 6. stavak 1. točke (b) i (c), kao i članak 7. točke (c) i (e) Direktive 95/46 treba tumačiti na način da se ne protive nacionalnom propisu, poput onoga u glavnom postupku, koji poslodavcu nameće obvezu stavljanja upisnika radnog vremena na raspolaganje nacionalnom tijelu nadležnom za područje nadzora uvjeta rada kako bi mu omogućio neposredan uvid, pod uvjetom da je ta obveza nužna tom tijelu za izvršavanje zadaća nadzora primjene pravila u području uvjeta rada, a posebno u vezi s radnim vremenom. ${ }^{82}$

Članak 12. točka (a) Direktive 95/46/EZ propisuje: „Države članice osiguravaju da svaka osoba čiji se podaci obrađuju ima pravo dobiti od nadzornika: (a) bez prisile, u razumnim rokovima te bez pretjerane odgode ili troška potvrdu obrađuju li se ili ne podaci koji se na nju odnose te podatak barem u vezi svrhe obrade, vrste podataka te primatelje ili vrste primatelja kojima se podaci otkrivaju; obavijest u razumljivom obliku o podacima koji se obrađuju te bilo koje podatke o njihovom izvoru, ..." Dakle, države članice imaju obvezu osiguravanja da svaka osoba čiji se podaci obrađuju može od nadzornika dobiti obavijest o svim podacima te vrste koje on obrađuje, a koji se odnose na nju. Ipak, državama članicama je ostavljena „mogućnost utvrđivanja konkretnog materijalnog oblika te obavijesti, ako je ,razumljiva“, odnosno ako omogućava osobi čiji se podaci obrađuju dobivanje

80 Toč. 44. presude Suda EU-a od 17. srpnja 2014. u spojenim predmetima C-141/12 Y. S. protiv Minister voor Immigratie, Integratie en Asiel i C-372/12 Minister voor Immigratie, Integratie en Asiel protiv M., S., ECLI:EU:C:2014:2081.

81 C-201/14, Smaranda Bara i dr. protiv Președintele Casei Naționale de Asigurări de Sănătate, Casa Naţională de Asigurări de Sănătate, Agenţia Naţională de Administrare Fiscală (ANAF), ECLI:EU:C:2015:638.

82 Rješenje Suda (osmo vijeće) od 19. lipnja 2014. (zahtjev za prethodnu odluku Tribunal do Trabalho da Covilhã - Portugal) - Pharmacontinente-Saúde e Higiene SA $i$ drugi protiv Autoridade Para As Condições do Trabalho (ACT), (Predmet C-683/13) ECLI:EU:C:2014:2028. 
uvida $\mathrm{u}$ te podatke te provjeru njihove točnosti i usklađenosti njihove obrade $\mathrm{s}$ tom direktivom, a kako bi se ta osoba mogla, ako je primjenjivo, koristiti pravima koja joj dodjeljuju članak 12. točke (b) i (c), članak 14., članak 22. i članak 23. te direktive. Stoga, budući da drugi oblik obavijesti može u potpunosti zadovoljiti cilj tog prava na pristup, osoba čiji se podaci obrađuju ni na temelju članka 12. točke (a) Direktive 95/46 ni na temelju članka 8. stavka 2. Povelje ne može imati pravo na dobivanje preslike izvornog dokumenta ili spisa u kojem se ti podaci nalaze. Kako se osobi čiji se podaci obrađuju ne bi dao pristup drugim informacijama, osim osobnim podacima koji se odnose na nju, ta osoba može dobiti presliku izvornog dokumenta ili spisa u kojem su te druge informacije učinjene nečitljivima." ${ }^{\text {"83 }}$

Prema jednoj presudi Suda EU-a: „Članak 12. točku (a) Direktive 95/46/EZ Europskog parlamenta i Vijeća od 24. listopada 1995. o zaštiti pojedinaca u vezi s obradom osobnih podataka i o slobodnom protoku takvih podataka treba tumačiti na način da mu nije protivna naplata troškova prilikom obavijesti javnog tijela o osobnim podacima. Članak 12. točku (a) Direktive $95 / 46$ treba tumačiti na način da, kako bi se osiguralo da naplaćeni troškovi prilikom korištenja prava na pristup osobnim podacima ne budu pretjerani u smislu ove odredbe, njihov iznos ne smije prelaziti trošak obavijesti o tim podacima. Na nacionalnom je sudu da učini potrebne provjere imajući u vidu okolnosti glavnog postupka.“"84

Odredbom članka 13. stavak 1. Direktive 95/46/EZ propisano je da države članice mogu donijeti propise za ograničavanje područja primjene obveza i prava iz članka 6. stavka 1., članka 10., članka 11. stavka 1. te članka 12. i 21. Direktive kada takvo ograničavanje predstavlja potrebne mjere za zaštitu: (a) nacionalne sigurnosti; (b) obrane; (c) javne sigurnosti; (d) sprječavanja, istrage, otkrivanja i progona kaznenih djela ili kršenja etike zakonom uređenih djelatnosti; (e) važnoga gospodarskog ili financijskog interesa države članice ili Europske unije, uključujući novčana, proračunska i porezna pitanja; (f) nadzora, inspekcije ili regulatorne funkcije povezane, čak i povremeno, s izvršavanjem javnih ovlasti u slučajevima iz točke (c), (d) i (e); (g) zaštite osobe čiji se podatci obrađuju ili prava i slobode drugih. Prema praksi Suda EU-a članak 13. stavak 1. Direktive 95/46/EZ treba tumačiti na način da „države članice nemaju obvezu, nego mogućnost prenijeti u svoje nacionalno pravo jednu ili više iznimaka od obveze obavještavanja osobe čiji se podaci obrađuju o obradi njihovih osobnih podataka, koje su predviđene tim stavkom. Aktivnost privatnog detektiva koji djeluje za račun profesionalnog tijela kako bi istražio kršenje etike u zakonom uređenim djelatnostima, u ovom slučaju profesije trgovca nekretninama, spada pod iznimku iz članka 13. stavka 1. točke (d) Direktive 95/46/EZ." ${ }^{\text {85 }}$

83 Toč. 57. i 58. presude Suda EU-a od 17. srpnja 2014. u spojenim predmetima C-141/12 Y. S. protiv Minister voor Immigratie, Integratie en Asiel i C-372/12 Minister voor Immigratie, Integratie en Asiel protiv M., S., ECLI:EU:C:2014:2081.

84 C-486/12, presuda od 12. prosinca 2013., ECLI:EU:C:2013:836.

85 Presuda Suda (treće vijeće) od 7. studenog 2013. (zahtjev za prethodnu odluku Cour constitutionnelle - Belgija) - Institut professionnel des agents immobiliers (IPI) protiv Geoffreyja Engleberta, Immo 9 SPRL, Grégory Francotte (Predmet C-473/12). 
U presudi Općeg suda (šesto vijeće) od 3. prosinca 2015. povodom odštetnog zahtjeva radi ishođenja naknade štete koju je tužitelj navodno pretrpio zbog prenošenja određenih uz njega vezanih osobnih (zdravstvenih) podataka na internetskoj stranici Parlamenta se navodi da iz sudske prakse proizlazi da izrazu „podaci koji se tiču zdravlja“ treba dati široko tumačenje tako da obuhvaća podatke o svim kako fizičkim tako i duševnim aspektima zdravlja određene osobe. Međutim, kako ističe Sud taj se pojam ne smije proširivati do te mjere da uključuje izraze koji ne dovode do otkrivanja bilo kakvog podatka o zdravlju ili zdravstvenom stanju osobe. ${ }^{86,87}$

86 Predmet T-343/13 (CN protiv Europskog parlamenta), ECLI:EU:T:2015:926.

87 Okolnosti spora, toč. 1. - 14. presude: „1. Tužitelj, CN, do 2011. bio je dužnosnik Vijeća Europske unije. Isti je 23. rujna 2009. Europskom parlamentu, putem obrasca dostupnog na njegovoj internetskoj stranici, podnio predstavku vezano uz potporu odobrenu članovima obitelji s invaliditetom europskog dužnosnika, poteškoće s kojima se susreću europski dužnosnici koji tijekom karijere iskuse zdravstvene probleme i loše postupanje Vijeća u njegovu predmetu. 2 . Vijeće se 8. siječnja 2010. konzultiralo s Europskom komisijom, sukladno članku 202. stavku 6. Poslovnika Parlamenta (SL 2011., L 116, str. 1.), koji je prema tekstu iz srpnja 2014. postao članak 216. stavak 6. Poslovnika. 3. Odbor za predstavke Parlamenta 15. siječnja 2010. obavijestio je tužitelja da je njegova predstavka proglašena dopuštenom. 4. Nakon što je primio Komisijin odgovor, Odbor za predstavke odlučio je 15. ožujka 2010. zaključiti postupak po predstavci te je 14. lipnja 2010. o tome obavijestio tužitelja. 5. Parlament je nakon odbijanja predstavke o njoj na svojoj internetskoj stranici objavio dokument naslovljen „Priopćenje zastupnicima“. U Priopćenju se sažeto prenosi sadržaj predstavke kao i Komisijin odgovor. Konkretno, navodi se tužiteljevo ime te se pojašnjava da je tužitelja pogodila teška bolest koja predstavlja opasnost za njegov život te da njegov sin ima teške duševne ili tjelesne smetnje. 6. U svibnju 2011. Vijeće je tužitelju otvorilo bolovanje zbog njegova zdravstvenog stanja. 7. U travnju 2012. tužitelj je poslao dopis Komisijinoj službi „Kontaktni centar Europe Direct“ koja ga je 10. travnja 2012. proslijedila Parlamentu. Tužitelj je u dopisu tražio da se Priopćenje povuče s internetske stranice Parlamenta. 8. Parlament je 20. travnja 2012. tužitelju odgovorio da je Priopéenje povukao s interneta. 9. Tužitelj je 31. kolovoza 2012. putem svojeg savjetnika ponovio zahtjev jer su dotični osobni podaci po njegovim navodima još uvijek bili vidljivi na internetskoj stranici Parlamenta. 10. Parlament je 24. rujna 2012. odgovorio da je objava Priopćenja bila zakonita. Dodao je da će tužiteljevi osobni podaci svejedno biti uklonjeni s interneta, bez obzira na to što za to ne postoji nikakva pravna obveza. 11. Parlament je u odgovoru na pisano pitanje Općeg suda naveo da su posljednje radnje uklanjanja glede uobičajenih pretraživača obavljene 8. listopada 2012. 12. Tužiteljev savjetnik je 4. prosinca 2012. ponovio zahtjev navodeći da su dotični osobni podaci i dalje vidljivi na internetu. 13. Parlament je tužiteljevom savjetniku 10. siječnja 2013. odgovorio kako smatra da je njegovo postupanje zakonito. Dodao je da su bez obzira na to svi dokumenti dostupni na njegovoj internetskoj stranici obrađeni ili se obrađuju u cilju uklanjanja tužiteljevih osobnih podataka. 14. Tužitelj tvrdi da su dotični osobni podaci na internetu bili dostupni barem do tog posljednje navedenog datuma.“ 


\section{REFORMA U ZAS̆TITI OSOBNIH PODATAKA U EUROPSKOJ UNIJI}

Reforma okvira za zaštitu podataka osobito je osjetljiva. U srpnju 2015. Europski nadzornik za zaštitu podataka dao je Preporuke o mogućnostima EU-a u pogledu reforme zaštite podataka. ${ }^{88}$ Kako se navodi u jednom godišnjem izvješću Europskog nadzornika ,reformiranje okvira za zaštitu podataka predstavlja jedan od najvećih i najsloženijih izazova za zakonodavce u EU-u posljednjih godina. “89 Ona bi trebala odgovoriti brojnim izazovima suvremenog digitalnog doba..$^{90}$

Veliku (povijesnu) reformu zaštite podataka (s ciljem ojačanja prava pojedinaca na zaštitu podataka te poboljšanja poslovnih mogućnosti olakšanjem slobodnog protoka osobnih podataka na jedinstvenom digitalnom tržištu) Komisija je predložila početkom 2012. godine (Opća uredba o zaštiti podataka).91,92 Do današnjeg dana tekst Uredbe koji je predložila Komisija doživio je određene, u nekim dijelovima bitne, izmjene. ${ }^{93}$

Ako bude usvojena, Opća uredba o zaštiti podataka će utjecati na sve pojedince (dakle i pacijente) u EU-u, na sve organizacije u EU-u koje obrađuju osobne podatke te organizacije izvan EU-a koje obrađuju osobne podatke o pojedincima

88 Preporuke Europskog nadzornika za zaštitu podataka o mogućnostima EU-a u pogledu reforme zaštite podataka, Službeni list EU C 301, 12. 09. 2015. (dalje u tekstu: preporuke Europskog nadzornika za zaštitu podataka 2015.).

89 Europski nadzornik za zaštitu podataka, Godišnje izvješće za 2014., Luxembourg: Ured za publikacije Europske unije, 2015., str. 5.

90 „Među izazovima s kojima se suvremeno društvo suočava su i potrebe za zaštitom privatnosti na internetu, jamčenjem pristupa internetu te sprečavanjem zlouporabe videonadzora, oznaka za radiofrekvencijsku identifikaciju (pametnih čipova), bihevioralnog oglašavanja, internetskih pretraživača i društvenih mreža." http://www.europarl.europa.eu/ftu/pdf/hr/ FTU_5.12.8.pdf (10.2.2016.).

$91 \operatorname{COM}(2012) 0011$ završna verzija: Prijedlog Uredbe Europskog parlamenta i Vijeća o zaštiti pojedinaca u vezi s obradom osobnih podataka i o slobodnom protoku takvih podataka (Opća uredba o zaštiti podataka).

92 Iste godine Komisija je predložila i Direktivu Europskog parlamenta i Vijeća o zaštiti pojedinaca pri obradi osobnih podataka od strane nadležnih tijela u svrhe sprečavanja, istrage, otkrivanja ili progona kaznenih djela ili izvršavanja kaznenopravnih sankcija te slobodnom kretanju takvih podataka. Europski parlament donio je svoje izvješće o prijedlogu ove Direktive 12. ožujka 2014. Europski nadzornik za zaštitu podataka dao je 8. ožujka 2012. mišljenje o prijedlogu Komisije. Vidi: http://data.consilium.europa.eu/doc/document/ST12555-2015-INIT/hr/pdf (17.1.2016.).

93 Oko 4.000 izmjena i dopuna tijekom prvog čitanja u Europskom parlamentu. Nakon prvog čitanja Europski parlament donio je zakonodavnu rezoluciju od 12. ožujka 2014. o prijedlogu Uredbe Europskog parlamenta i Vijeća o zaštiti pojedinaca pri obradi osobnih podataka i o slobodnom kretanju takvih podataka (Opća uredba o zaštiti podataka) (COM(2012) 0011 - C7-0025/2012 - 2012/0011(COD)) (Redovni zakonodavni postupak: prvo čitanje)., Navedeno prema: Izvršni sažetak mišljenja Europskog nadzornika za zaštitu podataka o budućem razvoju područja slobode, sigurnosti i pravde, Službeni list EU C 224, 15. 07. 2014., str. 28. 
u EU-u. ${ }^{94}$ U pravnoj literaturi postoji sumnja da će novi pravni okvir za zaštitu podataka donijeti nešto novo i bolje od postojeće regulacije, te uspjeti zadovoljite stvarne potrebe zdravstvenog sektora i moći unaprijediti sigurnost pacijenata. ${ }^{95}$ Tako i Europski nadzornik ističe da će donošenje EU-ovog paketa reformi u području zaštite podataka koji je usmjeren na budućnost biti impresivno, ali unatoč tome nepotpuno postignuće. ${ }^{96}$

Predloženom Općom uredbom, što se tiče materijalnog područja primjene (čl. 2. st. 1.), Uredba se primjenjuje na obradu osobnih podataka koji se u cijelosti ili djelomično obrađuju automatiziranim putem, bez obzira na metodu obrade, te na obradu osobnih podataka koji čine dio sustava podataka ili će činiti dio sustava podataka obradom koja nije automatizirana. Vezano uz teritorijalno područje primjene (čl. 3), pojašnjava da će poduzeća koja nemaju poslovni nastan u Uniji morati primjenjivati pravo EU-a u vezi sa zaštitom podataka kada nude robu i usluge europskim potrošačima ili prate njihovo ponašanje, odnosno temeljno pravo na zaštitu podataka poštovat će se neovisno o geografskoj lokaciji poduzeća ili njegova pogona za obradu. ${ }^{97}$

Sukladno članku 9. stavak 1. prijedloga Uredbe podatci u vezi sa zdravljem ulaze u posebnu kategoriju podataka čija je obrada zabranjena. Međutim, predviđeno je (čl. 9. st. 2(h)) da se navedeni stavak ne primjenjuje u određenim slučajevima, kao što je npr. slučaj kada je obrada podataka o zdravstvenom stanju nužna u zdravstvene svrhe i podliježe uvjetima i mjerama zaštite utvrđenima člankom 81 . Uredbe koji određuje sljedeće: ,... obrada osobnih podataka o zdravstvenom stanju mora se provoditi na temelju zakonodavstva Unije ili zakonodavstva države članice kojim se osiguravaju prikladne, dosljedne i posebne mjere za očuvanje interesa i temeljnih prava osobe čiji se podaci obrađuju, u mjeri u kojoj su potrebne i razmjerne i na način ...".

U 42. uvodnoj izjavi Uredbe stoji da bi se odstupanja od zabrane obrade osjetljivih kategorija podataka također trebala dopustiti kad za to postoji zakonska osnova i pod uvjetom da postoje odgovarajuće mjere za zaštitu osobnih podataka i drugih temeljnih prava kad je to opravdano zbog javnog interesa, te posebno u zdravstvene svrhe, na područjima kao što je javno zdravlje i socijalna zaštita, upravljanje zdravstvenim službama, posebno kako bi se osigurala kvaliteta i isplativost postupaka koji se koriste za rješavanje zahtjeva za ostvarenje pogodnosti i usluga iz sustava zdravstvenog osiguranja ili u svrhe povijesnog, statističkog i

94 Preporuke Europskog nadzornika za zaštitu podataka, str. 2.

95 Tako: HERVEG, Jean, Data Protection and the Patient's Right to Safety, European Journal of Health Law, vol. 21., 2014., str. 269.; Vidi: MOEREL, Lokke, Big Data Protection, How to Make the Draft EU Regulation on Data Protection Future Proof, Tilburg University, 2014., str. 51. - 54. http://www.debrauw.com/wp-content/uploads/NEWS\%20-\%20PUBLICATIONS/ Moerel_oratie.pdf (17.2.2016.).

96 Preporuke Europskog nadzornika za zaštitu podataka, str. 5.

97 Komunikacije Komisije Europskom parlamentu i Vijeću: Ponovna uspostava povjerenja u protoku podataka između EU-a i SAD-a, COM(2013)846 final, Bruxelles, 27. 11. 2013. 
znanstvenog istraživanja ${ }^{98}$ ili za usluge arhiviranja. ${ }^{99}$

Uzimajući u obzir navedeni prijedlog Komisije upućen Europskom parlamentu i Vijeću u brojnim (posebice „glavnim“) institucijama EU-a neprestano se vode žustre rasprave o brojnim osjetljivim prijedlozima (pitanjima i problemima) vezanim uz problematiku upotrebe i zaštite (osobnih) podataka, uključujući i osobne podatke u vezi sa zdravljem (pacijenata). Europski parlament, Vijeće i Europska komisija započele su 24. lipnja 2015. pregovore u vezi sa suodlučivanjem o predloženoj Općoj uredbi o zaštiti podataka (neformalni „trijalog”) čiju osnovu čine navedeni prijedlog Komisije iz siječnja 2012., zakonodavna rezolucija Parlamenta od 12. ožujka 2014. o prijedlogu Opće uredbe o zaštiti podataka ${ }^{100}$ i opći pristup Vijeća usvojen 15. lipnja 2015. godine. ${ }^{101,102}$

\section{ZAKLJUČAK}

Zaštita osobnih podataka koja proizlazi iz izričite obveze predviđene u brojnim međunarodnim i nacionalnim propisima ima osobitu važnost za pravo na poštovanje privatnog života. Pravo na zaštitu osobnih podataka i pravo na poštovanje privatnog života dva su različita, ali usko povezana temeljna prava. Prema ustaljenoj praksi Sud EU-a pravo na zaštitu osobnih podataka nužno je ostvarivati u ravnoteži s drugim temeljnim pravima. To pravo ima osobitu važnost za pravo na poštovanje privatnog života. Osobni zdravstveni podatci bitan su element privatnosti. Ti su podatci posebna, vrlo osjetljiva kategorija podataka. Stoga je i obrada takvih podataka posebno osjetljiva i mora se uvijek provoditi uz očuvanje interesa,

98 „Pravila o zaštiti podataka ne smiju ometati povijesna, statistička i znanstvena istraživanja koja su zaista u javnom interesu. Oni koji su odgovorni moraju poduzeti potrebne mjere kako bi spriječili da se osobni podaci upotrebljavaju protiv interesa pojedinca, obraćajući posebnu pozornost na pravila koja uređuju osjetljive informacije u vezi s, primjerice, zdravljem.“ Preporuka nadzornika

99 Prema prvotnom prijedlogu Komisije ova uvodna izjava je glasila: „Odstupanja od zabrane obrade osjetljivih kategorija podataka također bi se trebala dopustiti kad za to postoji zakonska osnova $\mathrm{i}$ - pod uvjetom da postoje odgovarajuće mjere za zaštitu osobnih podataka i drugih temeljnih prava - kad je to opravdano zbog javnog interesa, te posebno u zdravstvene svrhe, na područjima kao što je javno zdravlje i socijalna zaštita, upravljanje zdravstvenim službama, posebno kako bi se osigurala kvaliteta i isplativost postupaka koji se koriste za rješavanje zahtjeva za ostvarenje pogodnosti i usluga iz sustava zdravstvenog osiguranja ili u svrhe povijesnog, statističkog i znanstvenog istraživanja."

100 Zakonodavna rezolucija Europskog parlamenta od 12. ožujka 2014. o prijedlogu Uredbe Europskog parlamenta i Vijeća o zaštiti pojedinaca pri obradi osobnih podataka i o slobodnom kretanju takvih podataka (Opća uredba o zaštiti podataka) (COM(2012)0011 - C7-0025/2012 - 2012/0011(COD)).

101 Vijeće Europske unije, Prijedlog uredbe Europskog parlamenta i Vijeća o zaštiti pojedinaca u vezi s obradom osobnih podataka i o slobodnom protoku takvih podataka (Opća uredba o zaštiti podataka) - priprema općeg pristupa, Međuinstitucijski predmet: 2012/0011 (COD), Dokument br. 9565/15, Bruxelles, 11. lipanj 2015., http://data.consilium.europa.eu/doc/ document/ST-9565-2015-INIT/hr/pdf (14.2.2016.).

102 Preporuke Europskog nadzornika za zaštitu podataka 2015., str. 1. 
temeljnih prava i dostojanstva osobe čiji se podatci obrađuju. Pravo na zaštitu osobnih podataka u vezi sa zdravljem je pravo zaštite (legitimnih, moralnih i ekonomskih) interesa pojedinca koje se odnosi na učinkovitu zaštitu njegovih osobnih podataka u vezi sa zdravljem od rizika zlouporabe kao i od svih neustavnih, nezakonitih, neopravdanih pristupa i korištenja, te na sankcioniranje protupravnog korištenja i zlouporabe. ${ }^{103}$

S obzirom na narušenost povjerenja europskih građana u povjerljivost osobnih podataka, posljednjih je godina zabrinutost oko privatnosti i jamstva temeljnog prava na zaštitu osobnih podataka zasigurno s razlogom postala naglašenija nego ikada. ${ }^{104}$ Opravdano se postavlja pitanje postoji li u sadašnjem trenutku odgovarajuća (učinkovita) zaštita osobnih podataka građana EU-a, uključujući osobne zdravstvene podatke. Možda je preteška konstatacija, ali ne i daleko od istine, da su u današnje digitalno doba temeljna prava pojedinca na privatnost i zaštitu osobnih podataka (vezanih uz zdravstveno stanje) irealna i da je njihova nemoć očevidna. ${ }^{105}$ Pojedinci (pacijenti) imaju sve manji nadzor nad osobnim podatcima vezanim uz zdravstveno stanje.

Brojni propisi EU-a sadrže odredbe o zaštiti podataka pojedinca koji se odnose na stanje njegova zdravlja. Međutim, u sadašnjem trenutku ne postoji regulativa koja se specifično bavi problemima zaštite osobnih podataka u vezi sa zdravljem na europskoj razini.

Donošenje jakog, jasnog i suvremenog okvira za zaštitu podataka u EU-u koji će se moći nositi s brojnim izazovima suvremenog digitalnog doba i globalnog digitalnog tržišta, te podizanje kulture privatnosti i zaštite osobnih podataka na višu razinu, nema alternative. Kako to ističe Europski nadzornik za zaštitu podataka: „U današnjem digitalnom okruženju poštovanje zakona nije dovoljno; moramo uzeti u obzir etičku dimenziju obrade podataka. Temeljna prava na privatnost i zaštitu osobnih podataka postala su važnija za zaštitu ljudskog dostojanstva nego ikada prije." ${ }^{106}$

Skori odgovor institucija EU-a na brojne i osjetljive izazove suvremenog (digitalnog) doba u području zaštite privatnosti i osobnih podataka (Opća uredba o zaštiti podataka) sigurno će utjecati i na pitanje zaštite osobnih podataka u vezi sa zdravljem kao posebne kategorije podataka. Novi pravni okvir za zaštitu podataka treba olakšati protok zdravstvenih podataka, ali istodobno mora omogućiti učinkovitu zaštitu osobnih (zdravstvenih) podataka od rizika zloporabe kao i od svih nezakonitih, neželjenih, nepotrebnih pristupa i korištenja tih podataka. Drugim riječima, mora se osigurati visoka razina zaštite osobnih podataka u vezi

103 Vidi: http://azop.hr/prava-ispitanika/detaljnije/prava-ispitanika (22.1.2016.).

104 Vidi: Izvršni sažetak mišljenja Europskog nadzornika za zaštitu podataka o budućem razvoju područja slobode, sigurnosti i pravde, Službeni list C 224, 15. 7. 2014., str. 27.

105 Vidi: VILLEY, Michel, Pravo i prava čovjeka, Disput, Zagreb, 2002., str. 10.

106 Izvršni sažetak Mišljenja br. 4/2015 Europskog nadzornika za zaštitu podataka o mobilnom zdravstvu, „Prema novoj digitalnoj etici: Podatci, dostojanstvo i tehnologija” Službeni list EU C 392., 25. 11. 2015., str. 9. 
sa zdravljem. Također, potrebno je neprestano jačati i razvijati nove tehnologije i mehanizme otkrivanja i nadzora kojima se u praksi omogućuju prepoznavanje i sankcioniranje mogućih povreda temeljnog prava na zaštitu osobnih podataka u vezi sa zdravljem. ${ }^{107}$

Sustav pravne zaštite osobnih podataka u vezi sa zdravljem mora učinkovito balansirati prava pojedinca i opće društvene interese. Pravila o zaštiti osobnih podataka ne smiju ometati istraživanja, razvoj i inovacije koje su zaista u javnom interesu, ali pri tom je nužno poduzeti potrebne mjere kako bi se spriječilo da se osobni podatci upotrebljavaju protiv interesa (dobrobiti) pojedinca, obraćajući posebnu pozornost na zaštitu osobnih podataka u vezi sa zdravljem. ${ }^{108}$

107 Vidi: toč. 81. presude Suda EU-a od 6. listopada 2015. u predmetu C-362/14 (Schrems).

108 Vidi: Preporuke Europskog nadzornika za zaštitu podataka 2015., str. 4. 


\section{Summary}

\section{LEGAL FRAMEWORK FOR THE PROTECTION OF PERSONAL DATA (HEALTH-RELATED) IN THE LAW OF THE EUROPEAN UNION}

The right to the protection of personal data is a fundamental right enshrined in numerous international and national legal documents. Personal data related to health status enjoy special protection. The importance of the right to the protection of personal data (health-related) has been highlighted in the jurisprudence of the European Court of Human Rights and the Court of the European Union. This paper provides an overview of the most important legal sources in the protection of the personal (health) data in the European Union and relevant case law of the European Court of Human Rights and the Court of the European Union. At the same time the authors give attention to the current extremely complex reform of the legal framework for the protection of (personal) data in the European Union.

Key words: privacy, personal data, Directive 95/46 EC, protection of the personal health data.

\section{Zusammenfassung}

\section{DER RECHTLICHE RAHMEN FÜR DEN (GESUNDHEITS) DATENSCHUTZ IM EU-RECHT}

Das Recht auf Schutz von persönlichen Daten ist in mehreren internationalen Abkommen und nationalen Regelungen festgeschriebenes Grundrecht. Personenbezogene Daten im Rahmen der Gesundheit genießen ein besonders hohes Schutzniveau. Letzteres ergibt sich auch aus der Rechtsprechung des Europäischen Gerichthofs für Menschenrechte, wie auch des Gerichtshofs der Europäischen Union. Die Autoren betrachten die wichtigsten Rechtsquellen im Hinblick auf den Schutz von Personenbezogenen (Gesundheits)Daten im EU-Recht und Rechtsprechung der oben genannten Gerichsthöfe. Außerdem überlegen sie die zu ausfürhlich gestaltete Reform des Rahmens für den Schutz von personenbezogenen (Gesundheits)Daten in der EU.

Schlüsselwörter: Datenschutz, personenbezogene Daten, Richtlinie 95/46/EG, Gesundheitsdatenschutz. 


\section{Riassunto}

\section{IL QUADRO NORMATIVO DELLA PROTEZIONE DEI DATI PERSONALI (SULLA SALUTE) NEL DIRITTO DELL'UNIONE EUROPEA}

Il diritto alla protezione dei dati personali è un diritto fondamentale che trova conferma in numerosi documenti internazionali e nazionali. Godono di particolare protezione i dati personali relativi allo stato di salute. L'importanza del diritto alla protezione dei dati personali (sulla salute) viene evidenziata anche dalla giurisprudenza della Corte europea dei diritti dell'uomo e della Corte di giustizia dell'Unione europea. Gli autori in questo contributo passano in rassegna le fonti giuridiche più significative in materia di protezione dei dati personali (sulla salute) nel diritto dell'Unione europea, come pure nella giurisprudenza della Corte europea dei diritti dell'uomo e della Corte di giustizia dell'Unione europea, concentrandosi sull'attuale complessa riforma del quadro normativo per la protezione dei dati (personali) nell'Unione europea.

Parole chiave: riservatezza, dati personali, Direttiva 95/46/CE, protezione dei dati personali sulla salute. 